\title{
In vitro iron enrichment experiments in the NE subarctic Pacific
}

\author{
P. W. Boyd ${ }^{1, *}$, D. L. Muggli ${ }^{1}$, D. E. Varela ${ }^{1}$, R. H. Goldblatt ${ }^{1}$, R. Chretien ${ }^{1}$, \\ K. J. Orians ${ }^{1,2}$, P. J. Harrison ${ }^{1}$ \\ 'Department of Oceanography, ${ }^{2}$ Department of Chemistry, University of British Columbia, Vancouver, \\ British Columbia, Canada V6T 1Z4
}

\begin{abstract}
There has been considerable debate about both the mechanisms controlling primary production, and the interpretation of data from Fe-enrichment experiments conducted in high nitrate-low chlorophyll (HNLC) regions. This paper presents results of 3 in vitro Fe-enrichment experiments performed in May 1993 and May 1994 at Ocean Station Papa (OSP) in the NE subarctic Pacific. Expt 1 (May 1993) considered jointly the influence of both Fe supply and microzooplankton herbivory on algal stocks, while the second (May 1993) investigated the influence of Fe supply on the partitioning of C, N and $\mathrm{Fe}$ between algal size classes. The third study (May 1994) monitored changes in phytoplankton stocks in Fe-enriched carboys containing mesozooplankton. Assuming similar environmental conditions in May 1993 and 1994, then the combined findings indicate that under ambient conditions autotrophic cells $<5 \mu \mathrm{m}$ compose $>70 \%$ of algal biomass, primarily utilized ammonium, showed no Femediated enhancement of N-normalized nitrate or ammonium uptake, and were thus unlikely to be Felimited. Although the coupling between grazer mortality and algal growth of these cells $(g / \mu)$ was ca $0.71 \pm 0.25$, they grew at close to maximal rates but exhibited negligible net growth rates, suggesting strong grazer control. Dissolved iron (DFe) supply promoted a rapid increase in the abundance of large, initially rare, diatoms (mainly Nitzschia spp.) over $6 \mathrm{~d}$, elevated diatom growth rates to close to their theoretical maximum and increased rates of incorporation of $\mathrm{N}$-normalized nitrate and Fe by these cells over time. Unlike the small cells, stocks of large autotrophs also increased in the controls; DFe measurements indicate that this was probably due to inadvertent Fe contamination. The development of a phytoplankton population, of a cell size probably too large to be grazed at a significant rate by microzooplankton, resulted in a decoupling of herbivory and algal growth. In addition, mesozooplankton herbivory appeared unable to prevent the accumulation of these large cells; in May 1994, Fe supply prompted an 8 -fold increase in algal stocks over $6 \mathrm{~d}$ in carboys where grazers equivalent to the maximum annual in situ pelagic abundance were present. The findings agree with the theories of others, that Fe supply rather than grazing provides the ultimate control over the phytoplankton community in the NE subarctic Pacific.
\end{abstract}

KEY WORDS: NE subarctic Pacific Iron enrichment Phytoplankton growth - Grazing pressure - Size fractions $\cdot \mathrm{C}, \mathrm{N}$, Fe uptake

\section{INTRODUCTION}

The NE subarctic Pacific is one of three oceanic regions characterized by low phytoplankton stocks despite persistently high concentrations of macronutrients (Miller et al. 1991). Recently, there has heen considerable debate about the mechanisms controlling primary

\footnotetext{
·E-mail: pboyd@unixg.ubc.ca
}

production in HNLC (high nitrate-low chlorophyll) regions (Chisholm \& Morel 1991). Explanations include grazing pressure (Frost 1991), low irradiance levels (Mitchell et al. 1991), and Fe supply (Martin 1990). Several of these explanations were tested during 5 to $7 \mathrm{~d}$ experiments in the NE subarctic Pacific and have variously supported the Fe (Martin et al. 1989, Coale 1991) or grazing hypotheses (Welschmeyer et al. 1991). Recently, a candidate theory has been developed which 
incorporates some of the above hypotheses and suggests that large phytoplankton are Fe-limited and small phytoplankton are under grazer control (Fe-grazing theory) in the NE subarctic Pacific (Miller et al. 1991) and in other HNLC regions (Cullen 1991, Frost 1991).

Several in vitro studies (such as Martin et al. 1989) have shown that Fe enrichment is taxon-specific, preferentially enhancing the growth rates of large diatoms in the NE subarctic Pacific. In other cases, such as the in situ Ironex 1 Equatorial Pacific experiment, the photosynthetic efficiency of all taxa, and thus of all cells, increased as a result of Fe supply (Kolber et al. 1994). As small phytoplankton $<5 \mu \mathrm{m}$ dominate algal biomass and production in both the NE subarctic Pacific (Booth et al. 1993) and Equatorial Pacific (Chavez et al. 1991) any shift in size spectra towards a dominance of large cells may alter the structure of the pelagic ecosystem. Recent work by Price et al. $(1991,1994)$ in the Equatorial Pacific indicated that nitrate uptake by small algal cells was unaffected by $\mathrm{Fe}$ enrichment, with these phytoplankters preferentially utilizing ammonium. In contrast, they observed that large phytoplankton were physiologically stimulated by Fe supply and utilized nitrate at elevated rates, relative to ambient conditions, during in vitro Fe-enrichment experiments. Neither Martin et al. (1989), nor Coale (1991) directly investigated the influence of Fe supply on the uptake and partitioning of inorganic $N$ species in the NE subarctic Pacific.

The Fe-enrichment experiments of Martin et al. (1989) and Coale (1991) were done at Ocean Station Papa (OSP) in August when mesozooplankton abundances were ca $50 \%$ of the annual maximum in the upper water column (Fulton 1978). While these studies provided some of the first evidence of Fe-limited phytoplankton, their findings were viewed as inconclusive as they did not assess herbivory or the representativeness of grazers in experimental vessels (Banse 1991a). Indeed, Coale (1991) reports on the likelihood of having conducted his experiments with considerably reduced mesozooplankton populations relative to ambient. Despite the advances made in our understanding by the SUPER (Subarctic Pacific Ecosystem Research) program, no successful Feenrichment experiment was performed by this group due to contamination problems (Miller et al. 1991). Although microand meso-zooplankton herbivory have been estimated in the NE subarctic Pacific over $24 \mathrm{~h}$ periods (Strom \& Welschmeyer 1991, Dagg 1993a), graz- ing has not been assessed during Fe-enrichment experiments. Also, in 5 to $6 \mathrm{~d}$ time series experiments at OSP that assessed mesozooplankton herbivory (Landry \& Lehner-Fournier 1988, Welschmeyer et al. 1991, Landry et al. 1993a), no measurement of Fe inadvertently added to the experimental vessel was performed and hence the potential role of Fe on phytoplankton stocks could not be determined.

Thus, experiments conducted at OSP have either been Fe-enrichment studies which did not explicitly consider grazing activity, or grazing experiments which did not take $\mathrm{Fe}$ enrichment into consideration. As the recent Fe-grazing theory of Miller et al. (1991) has not been rigorously tested to date in this region, aspects of Fe supply and grazing were investigated in the present study. In May 1993, 2 in vitro experiments, one to investigate the effects of Fe supply and microzooplankton herbivory on phytoplankton stocks, and another to study the effects of Fe supply on phytoplankton taxa within 3 size classes via the partitioning of C, N and Fe, were performed. In May 1994, a third in vitro experiment indirectly studied the effects of $\mathrm{Fe}$ supply and mesozooplankton herbivory on phytoplankton stocks via the provision of an Fe-enriched environment containing grazers.

\section{MATERIALS AND METHODS}

Experimental procedure. In May 1993 and May 1994, in vitro Fe-enrichment experiments were conducted at $\operatorname{OSP}\left(50^{\circ} \mathrm{N}, 145^{\circ} \mathrm{W}\right.$; Fig. 1). Seawater was

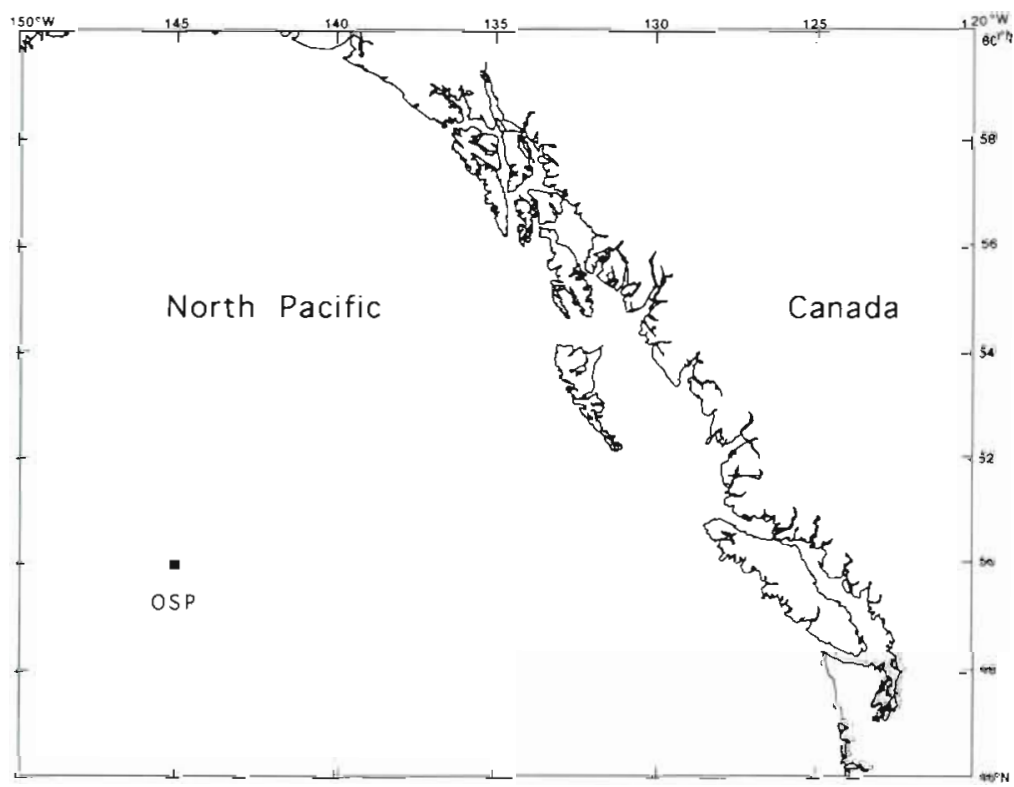

Fig. 1 Location of the NE subarctıc Pacific showing the posttion of Ocean Station Papa (OSP) 
collected at dusk (ca 23:00 h local time), within the 35 to $40 \mathrm{~m}$ deep mixed layer, from ca 10 to $15 \mathrm{~m}$ depth $\left(30 \% I_{0}\right)$ using $30 \mathrm{l}$ precleaned Go-Flo samplers (Bruland et al. 1979) used solely for trace metal-clean work (McKelvey \& Orians 1993). Go-Flo samplers, on Kevlar line, were opened by water pressure around $15 \mathrm{~m}$ and then lowered to a depth of ca $40 \mathrm{~m}$. The samplers were then retrieved and closed at ca $15 \mathrm{~m}$ depth while moving, using a Teflon messenger. All experimental manipulations were carried out in a portable positivepressure laboratory, the Go-Flo's remaining outside of the laboratory and being pressurized with filtered air in order to transport water through clean Bevaline tubing directly to 25 l polycarbonate carboys located within the laboratory. All carboys were acid-cleaned (Martin \& Gordon 1988) and then filled and preconditioned with open-ocean seawater for $36 \mathrm{~h}$ prior to sampling to permit equilibration and thus minimize adsorption of Fe by the container walls (Coale 1991). Seawater only, and seawater with soluble Fe to give a final concentration of $2 \mathrm{nM} \mathrm{Fe}$ ( $4 \mathrm{nM}$ Fe in May 1994), were added to control (C) and iron-addition (Fe) carboys, respectively. In all cases, Fe was added in a $1: 1.5$ Fe:EDTA solution to ensure initial Fe solubility, while not altering the overall metal speciation in the sample (Coale 1991).

To minimize contamination during the incubation, carboys were triple-wrapped in clean heavy-duty polyethylene bags; air was expelled, and each bag sealed with plastic ties. During all studies, carboys and all other related incubations (such as subsamples used in ${ }^{14} \mathrm{C}$ uptake experiments) were held in a deck incubator at ca $30 \% I_{0}$ and constant temperature was maintained with continuously flowing seawater (mixed layer temperature ca 9.5 to $10^{\circ} \mathrm{C}$ ). The bioassays took place from May 22 to 29, 1993 (microzooplankton herbivory: partitioning of $\mathrm{C}, \mathrm{N}, \mathrm{Fe}$ ) and from May 20 to 26, 1994 (Expt 3, mesozooplankton herbivory), respectively. In Expt 1, $1 \mathrm{C}$ and 1 Fe carboy were used and both were subsampled concurrently at $t=0$ and thereafter every $2 \mathrm{~d}$ for the duration of the experiment. In Expt 2, to provide more water for experimental manipulations, $3 \mathrm{C}$ and 3 Fe carboys were used, with $1 C$ and 1 Fe carboy being sampled at 2 d intervals. In Expt 3, 2 replicate $C$ and Fe carboys were subsampled daily. All other protocols were identical in Expts 1 to 3 .

Biological and chemical analyses. Samples for the following analyses were performed every $2 \mathrm{~d}$ in Expts 1 and 2: phytoplankton cell counts, size-fractionated chlorophyll a (chl a), dissolved iron (DFe), nitrate and ammonium. Size-fractionated particulate nitrogen (PN), particulate carbon (PC), and particulate iron (PFe) measurements were carried out during Expt 2 only. Due to the limited water volume available, no replication was possible for phytoplankton counts, size-fractionated chl a, nitrate, ammonium, PFe, PN and PC samples. During Expt 3, only chl a was analysed from daily subsamples. Phytoplankton samples for microscopical counts were preserved in Lugol's iodine and counted with an inverted microscope (Utermöhl 1958). To estimate size-fractionated chl a, phytoplankton were collected both under gravity on $18 \mu \mathrm{m}$ porosity $47 \mathrm{~mm}$ polycarbonate filters and using $<100 \mathrm{~mm} \mathrm{Hg}$ vacuum differential on $5 \mu \mathrm{m}$ and $0.2 \mu \mathrm{m}$ porosity $47 \mathrm{~mm}$ polycarbonate filters in a fractionation cascade (Joint \& Pomroy 1983). Chl a was measured by in vitro fluorometry (Parsons et al. 1984). Nitrate and ammonium were measured using a Technicon AutoAnalyzer following Wood et al. (1967) and Slawyk \& MacIsaac (1972), respectively. PN and PC, collected on precombusted GF/F filters, were analysed with a Carlo Erba nitrogen analyser NA 1500.

$\mathrm{DFe}$ concentrations $(<0.2 \mu \mathrm{m})$ were determined using a Varian graphite furnace atomic absorption spectrometer following Yang (1993). Results were expressed as $x \pm 1 \mathrm{SD}(\mathrm{n}=3)$. To assess microalgal Fe incorporation, size-fractionated PFe was collected onto 5 and $0.2 \mu \mathrm{m}$ porosity $47 \mathrm{~mm}$ acid-cleaned polycarbonate filters under $<100 \mathrm{~mm} \mathrm{Hg}$ vacuum differential. PFe samples were not rinsed with the Ti(III) citrate reagent (Hudson \& Morel 1989), due to the observed low external Fe concentrations and the possibility of contaminating samples with this treatment (Muggli et al. 1996). Therefore, PFe samples may include extracellularly bound $\mathrm{Fe}$. Prior to analysis, filters were digested with ultra-pure $\mathrm{HNO}_{3}$ (Seastar Chemicals) using microwave digestion apparatus.

Biological rate processes-Expts 1 and 2 (May 1993). Rate measurements in Expts 1 and 2 were initiated every 2 d using water from the carboys. No attempt was made to assess DFe concentrations of this water Size-fractionated post-incubation primary production was estimated using the ${ }^{14} \mathrm{C}$ technique following Joint et al. (1993) and using the same size fractions as for chl a. During all experiments, subsamples were held for $24 \mathrm{~h}$ commencing at local dawn in the deck incubator. Photosynthetic assimilation ratios were estimated from production and chl a data.

In Expt 2 only, size-fractionated $N$ uptake $(0.7-5 \mu \mathrm{m}$ and $>5 \mathrm{\mu m}$ ) were measured using ${ }^{15} \mathrm{~N}$ (Dugdale \& Goering 1967). Subsamples, from the same carboy, were inoculated with ${ }^{15} \mathrm{NO}_{3}{ }^{-}$or ${ }^{15} \mathrm{NH}_{4}{ }^{+}$at ca $10 \%$ of ambient concentrations and incubated in $1 \mathrm{l}$ polycarbonate bottles. After incubation, samples for ${ }^{15} \mathrm{~N}$ analysis were size-fractionated and collected on precombusted GF/F filters $(0.7 \mu \mathrm{m}$ nominal porosity) and analysed using the micro-Dumas dry combustion technique (Cochlan 1982, La Roche 1983) and a JASCO Model N-150 emission spectrometer (Fiedler \& Proksch 1975). Nitrogen uptake rates were calculated 
after Dugdale \& Wilkerson (1986). Corrections were not made for the dilution of ${ }^{15} \mathrm{NH}_{4}{ }^{+}$during uptake experiments.

Phytoplankton growth and microzooplankton herbivory-Expt 1. In Expt 1, herbivory experiments, based on changes in chl $a$, were initiated every $2 \mathrm{~d}$ using water from the carboys. The experiments were performed using the dilution technique (Landry 1993) at 4 dilutions $(0.2,0.4,0.8$ and 1.0$)$, with 2 acidcleaned 0.51 polycarbonate bottles per dilution. It was assumed that no mesozooplankton were present in the 0.51 bottles. Seawater from the carboys was prepared as a diluent by filtration through $47 \mathrm{~mm}$ diameter $0.2 \mu \mathrm{m}$ porosity precleaned polycarbonate filters. Analysis and interpretation of grazing mortality and specific algal growth rate followed Landry (1993). Prior to fitting, data sets were analysed for evidence of non-linearities between net phytoplankton growth and grazer density and fitted either by standard linear regression techniques (Landry \& Hassett 1982) or using the 3-point method (Gallegos 1989) as appropriate.

Comparison of carboy and net mesozooplankton abundances-Expt 3. In May 1994, shallow vertical (0 to $50 \mathrm{~m}$ ) net hauls $(296 \mu \mathrm{m}$ mesh, $57 \mathrm{~cm}$ diameter calibrated WP2 net) were obtained immediately prior to $(22: 00 \mathrm{~h})$ and just after $(23: 55 \mathrm{~h})$ water was obtained from the Go-Flos to initiate Expt 3. Data from hauls on mesozooplankton composition and abundance were later compared with the animals resident in the carboys (collected on $300 \mu \mathrm{m}$ Nitex mesh at $\mathrm{t}=6 \mathrm{~d}$ ). The depth of the haul and the mixed layer were similar, as it is known that seasonal migrants are found mainly within the upper water column in late spring (Mackas et al. 1993). The contents of the haul were preserved in $5 \%$ buffered formalin. In the laboratory, animals were counted and identified after subsampling using a stempel pipette for organisms $<2 \mathrm{~mm}$ ( 0.08 of total sample counted) and split in half using a Motoda splitter for organisms $>2 \mathrm{~mm}(0.5$ of total sample counted). The carboys contained a representative number of animals with respect to the nets $(70$ to $95 \%$ ), but the composition was slightly different with mainly Neocalanus flemingeri being observed in the carboys (Table 1). A net haul was also taken in May 1993, just prior to sampling with Go-Flos. As in 1994. the mesozooplankton sample was dominated by Neocalanus spp. which accounted for over $90 \%$ of community biomass. In May 1993, although active animals were observed in both $\mathrm{C}$ and $\mathrm{Fe}$ carboys, the number of resident animals was not counted. In May 1994, the health of the animals in the carboys was assessed by a qualitative microscopic examination of the gut contents at the end of the experiment. This analysis revealed no evidence of dead animals, and that the majority of the animals had material in their guts, indicative of active grazing.

Estimation of mesozooplankton herbivory-Expt 3 (May 1994). It was not possible to directly estimate herbivory during Expt 3 since grazing experiments require either 6 to 7 animals for each gut fluorescence measurement, or ca 81 per replicated sample for gut clearance experiments. These approaches would remove resident animals and/or use all experimental water (25 l) by Day 4 of an Fe-enrichment experiment. If larger carboys were used, the capture of animals from $C$ carboys would potentially result in considerable $\mathrm{Fe}$ contamination. As an alternative, an in vitro environment was provided which was/was not $\mathrm{Fe}$ enriched and contained grazers. The estimation of herbivory was based on 2 assumptions; (1) that carboys contained representative numbers of grazers and (2) that they were healthy. Herbivory was estimated indirectly using 2 approaches. In order to estimate community grazing rates, the highest measured species-specific grazing rates from Dagg's (1993a) comprehensive OSP study were used in conjunction with abundance data from the carboys (Table 1). In this approach, rates were based on zooplankton clearance at observed OSP chl a levels (ca $0.3 \mu \mathrm{g} \mathrm{l}^{-1}$ ). As mesozooplankton can alter their ingestion rates in response to increased prey concentrations, a second approach, which took into account increased clearance rates in response to elevated levels of chl $a$ in the Fe carboys, was used to estimate community grazing rates. The latter was based on Frost et al.'s (1983) study at OSP on the clearance rates (up to $0.43 \mathrm{l} \mathrm{cop.}^{-1} \mathrm{~d}^{-1}$ ) of Neocalanus spp. feeding on different concentrations of cultured diatoms.

Laboratory culture conditions for OSP cell isolates. Emiliania huxleyi $(<5 \mu \mathrm{m}$ diameter prymnesiophyte)

Table 1. Comparison of the sampling of mesozooplankton by Go-Flos and net hauls, May 1994. N. flem, N plum, N. crist denote Neocalanus flemingeri, $N$. plumchrus and $N$. cristatus, respectively. All Go-Flos and net hauls represent a time series taken during the late evening of May 20. Go-Flo casts $1 / 2$ and $3 / 4$ were used to fill $C$ and Fe carboys. Go-Flos on average sampled 271 of water. The mesozooplankton abundances of carboys 2 to 4 were determined at the end of the experiment. nd: not determined

\begin{tabular}{|lccccc|}
\hline $\begin{array}{l}\text { Sampling } \\
\text { method }\end{array}$ & $\begin{array}{c}\text { Time } \\
\text { (local) } \\
\text { (h) }\end{array}$ & $\begin{array}{c}\text { Mesozooplankton abundance }\left(\mathrm{m}^{-3}\right) \\
\text { C5 }\end{array}$ & $\begin{array}{c}\text { N. plum } \\
\text { C5 }\end{array}$ & $\begin{array}{c}\text { N. crist } \\
\text { C5 }\end{array}$ & $\begin{array}{c}\text { Total } \\
\text { animals }\end{array}$ \\
\hline Net 1 & $22: 00$ & 127 & 145 & 12 & 284 \\
Go-Flo 1 & & nd & & & nd \\
Go-Flo 2 & & 200 & & & 200 \\
Go-Flo 3 & & 200 & & & 200 \\
Go-Flo 4 & & 200 & & & 200 \\
Net 2 & $23: 55$ & 50 & 145 & 14 & 209 \\
\hline
\end{tabular}


and Actinocyclus sp. (15 to $60 \mu \mathrm{m}$ diameter centric diatom) were isolated from OSP samples,. The former was considered to be representative of cells from the dominant $<5 \mu \mathrm{m}$ autotrophic population, and the latter of large diatoms which compose $<10 \%$ of algal biomass, under ambient conditions respectively. Cultures were grown in triplicate in OSP water under saturating irradiances for growth $\left(150 \mu \mathrm{mol}\right.$ quanta $\left.\mathrm{m}^{-2} \mathrm{~s}^{-1}\right)$ on a $14 \mathrm{~h}$ light : $10 \mathrm{~h}$ dark cycle at $16^{\circ} \mathrm{C}$ with $30 \mu \mathrm{M}$ chelexed $\mathrm{NO}_{3}$ or $30 \mu \mathrm{M}$ chelexed $\mathrm{NH}_{4}, 5 \mu \mathrm{M}$ chelexed $\mathrm{PO}_{4}$ $50 \mu \mathrm{M} \mathrm{Si}, 10 \mu \mathrm{M}$ EDTA, and Aquil amounts of metals added except $\mathrm{Fe}$ (Price et al. 1990). Cells were harvested in $\log$ phase. Fe stress in the diatom was achieved by serial dilution in 'no $\mathrm{Fe}^{\prime}$ medium until $65 \%$ of $\mu_{\max }$ was achieved. Fe-replete cultures (defined as $95 \% \mu_{\max }$ ) of the diatom and the coccolithophore had 1000 and $100 \mathrm{nM} \mathrm{Fe}$ final concentrations added, respectively. Results of cell composition parameters represent averages for bath nitrate and ammonium grown cultures. Intracellular Fe values were obtained using the Ti(III) reagent of Hudson \& Morel (1989). It was assumed that diatoms and coccolithophores under ambient conditions at OSP were represented by cells growing at 65 and $95 \% \mu_{\max }$, respectively, whereas diatoms growing at $95 \% \mu_{\max }$ were considered $\mathrm{Fe}$ replete.

\section{RESULTS}

\section{Phytoplankton biomass and primary production}

In each experiment, chl $a$ increased in the Fe carboys with a ca $>7$-fold increase over the initial concentrations by Day $6_{\text {; }}$ levels of $>2.5,>4$ and ca $2 \mu \mathrm{g} \mathrm{l}^{-1}$ were measured in Expts 1, 2 and 3, respectively (Fig. 2). By Day 8 in Expt 1, the rate of increase of chl $a$ in the Fe carboy had slowed (Fig. 2A). Increases in chl a also occurred in the $\mathrm{C}$ carboys during all experiments, but were less marked (Fig. 2). Phytoplankton net growth rates were estimated from the instantaneous rates of change of chl a (Fig. 2). In order to assess the effect of Fe supply, linear regression equations ( $\operatorname{Zar} 1984$ ) for the slopes of the lines for the $\mathrm{C}$ and $\mathrm{Fe}$ carboys between Day 2 and the end of the experiment were compared using Student's $t$-test. Growth rates were statistically different $(p<0.05)$ for the $C$ and Fe carboys in Expts $1\left[0.35 \mathrm{~d}^{-1}(\mathrm{Fe}) ; 0.16 \mathrm{~d}^{-1}(\mathrm{C})\right]$ and $3\left[0.50 \mathrm{~d}^{-1}\right.$ (Fe); $0.24 \mathrm{~d}^{-1}$ (C)]. In Expt 2, growth rates were not statistically different at $p<0.05$, with the $t$-test yielding a value of $\mathrm{p}<0.2\left[0.47 \mathrm{~d}^{-1}(\mathrm{Fe}) ; 0.22 \mathrm{~d}^{-1}\right.$ (C) see Table 3]. Nitrate was ca 9 pM at the onset of Expts 1 and 2. decreased to $<1 \mu \mathrm{M}$ in the Fe carboys of both experiments by Day 6 , and was not detectable on Day 8 in Expt 1 In the controls, nitrate was ca $5 \mu \mathrm{M}$ at the end

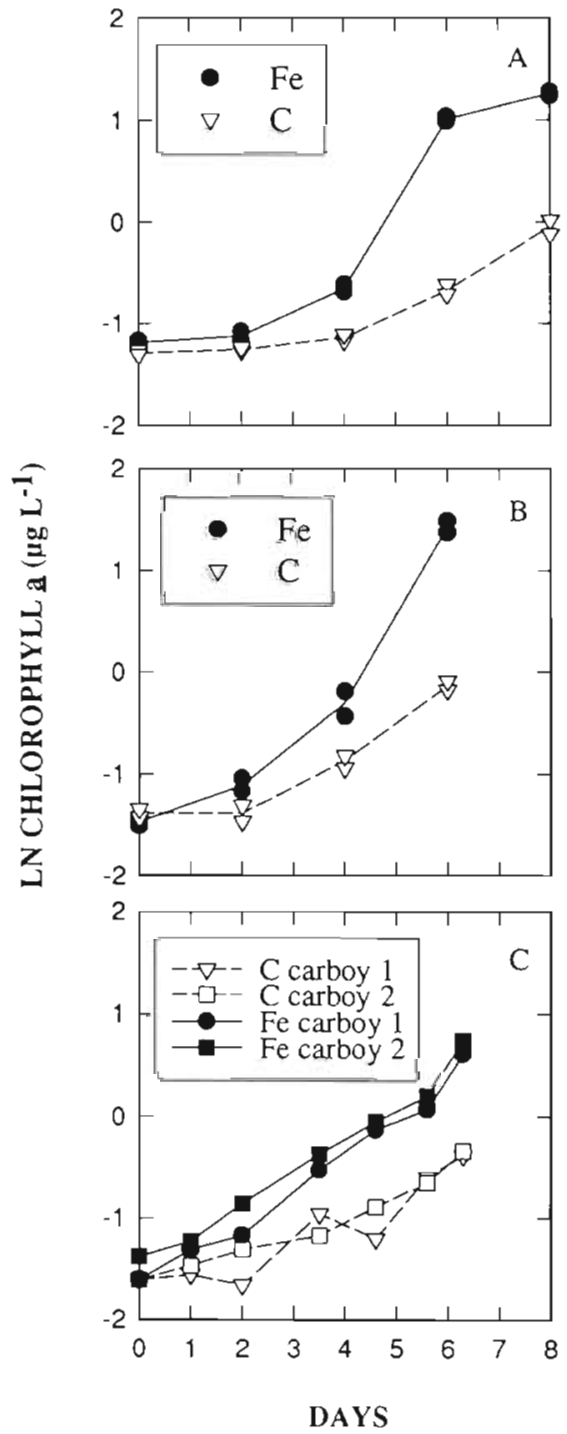

Fig. 2. Natural log of chl a $\left(\mu \mathrm{g}^{-1}\right)$ for $\mathrm{C}$ and Fe carboys in May 1993. (A) Expt 1; (B) Expt 2; and (C) May 1994

of both experiments. During May 1993, ammonium levels were initially ca $0.3 \mu \mathrm{M}$ for the $\mathrm{C}$ and Fe carboys, with a progressive decrease in concentration to $<0.05 \mu \mathrm{M}$ on Day 6 (data not shown).

As noted for chl a (Fig. 2), rates of primary production increased markedly over time in samples from the Fe carboys in Expts 1 and 2 (Fig. 3); on Day $6,{ }^{14} \mathrm{C}$ uptake rates were ca $250 \mathrm{\mu g} \mathrm{C} \mathrm{l}^{-1} \mathrm{~d}^{-1}$. By Day 8, production rates had declined in the Fe carboy in Expt 1 (Fig. $3 \mathrm{~A}$ ). In the $\mathrm{C}$ carboys, rates increased over the course of the experiment but did not exceed $60 \mathrm{\mu g} \mathrm{Cl}^{-1}$ $\mathrm{d}^{-1}$ (Fig 3). In general, photosynthetic assimilation ratios increased with time in both the $\mathrm{C}$ and Fe carboys during the May 1993 experiments (Fig. 4). After Day 6 in Expt 1, the ratio decreased in the Fe carboy to 


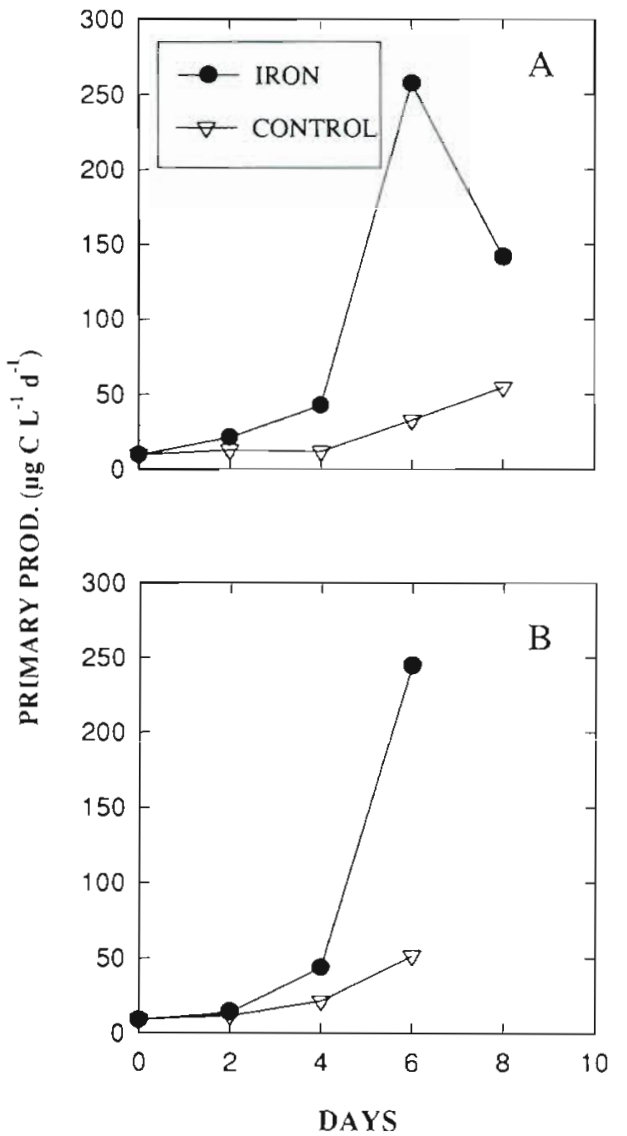

Fig. 3. Rates of primary production May 1993 for C and Fe carboys. (A) Expt 1; (B) Expt 2. No replicates

$<50 \mu \mathrm{g} \mathrm{C}(\mu \mathrm{g} \mathrm{chl} \mathrm{a})^{-1} \mathrm{~d}^{-1}$ (Fig. 4A). In Expt 2 (Fig. 4B), increases in the ratios in all carboys were less pronounced than in Expt 1

\section{Nitrogen uptake - Expt 2 (May 1993)}

In the $\mathrm{Fe}$ carboys, the $\mathrm{N}$-specific uptake rate of nitrate $\left(\mathrm{VNO}_{3}{ }^{-}\right)$for cells $>5 \mu \mathrm{m}$ increased 4-fold, $\left(0.0024\right.$ to $\left.0.0097 \mathrm{~h}^{-1}\right)$ from Day 2 to 4 , but decreased to $0.0040 \mathrm{~h}^{-1}$ by Day 6 (Fig. 5B). Although $\mathrm{VNO}_{3}{ }^{-}$also increased in the C carboy between Days 2 and 4 for the $>5 \mu \mathrm{m}$ fraction, this increase was from $0.0023 \mathrm{~h}^{-1}$ to ca $0.0055 \mathrm{~h}^{-1}$ and then remained constant until the end of the experiment (Fig. 5B). On Day $4, \mathrm{VNO}_{3}{ }^{-}$in the $\mathrm{Fe}$ carboy was twice that of the $\mathrm{C}$ carboy. In contrast, $\mathrm{VNO}_{3}{ }^{-}$for $0.7-5 \mu \mathrm{m}$ cells showed little change over time in the Fe carboy, with values similar to those in the control (Fig. 5A). Fe supply did not stimulate $\mathrm{VNH}_{4}{ }^{+}$in either size class (Fig. 5C, D). On Day 6 in both the $\mathrm{C}$ and $\mathrm{Fe}$ carboys, $\mathrm{VNO}_{3}{ }^{-}$was considerably reduced for the $0.7-5 \mu \mathrm{m}$ class compared to Day 4 .

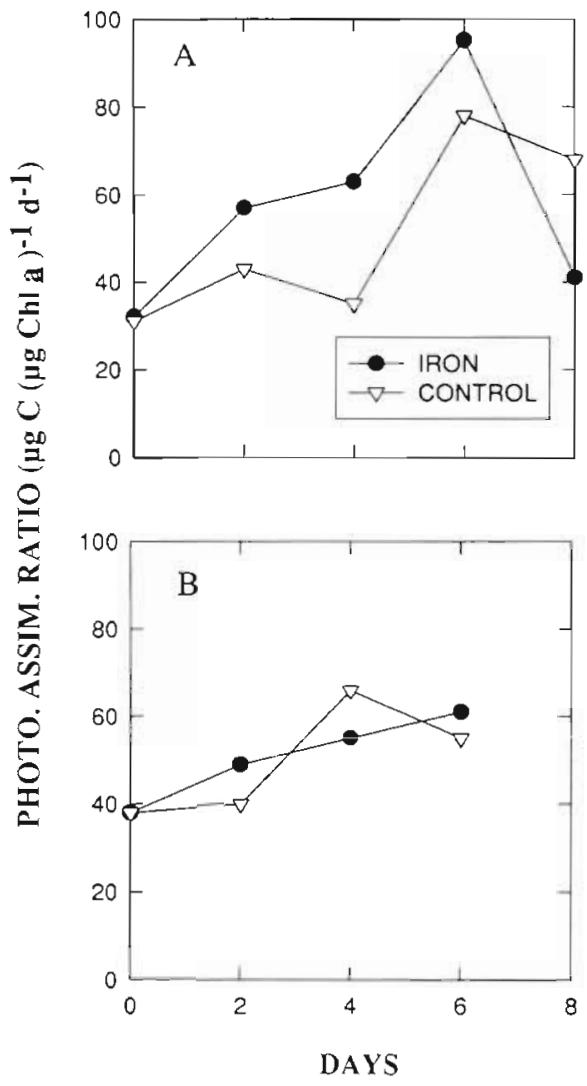

Fig. 4. Photosynthetic assimilation ratios May 1993 for $C$ and Fe carboys. (A) Expt 1; (B) Expt 2. No replicates
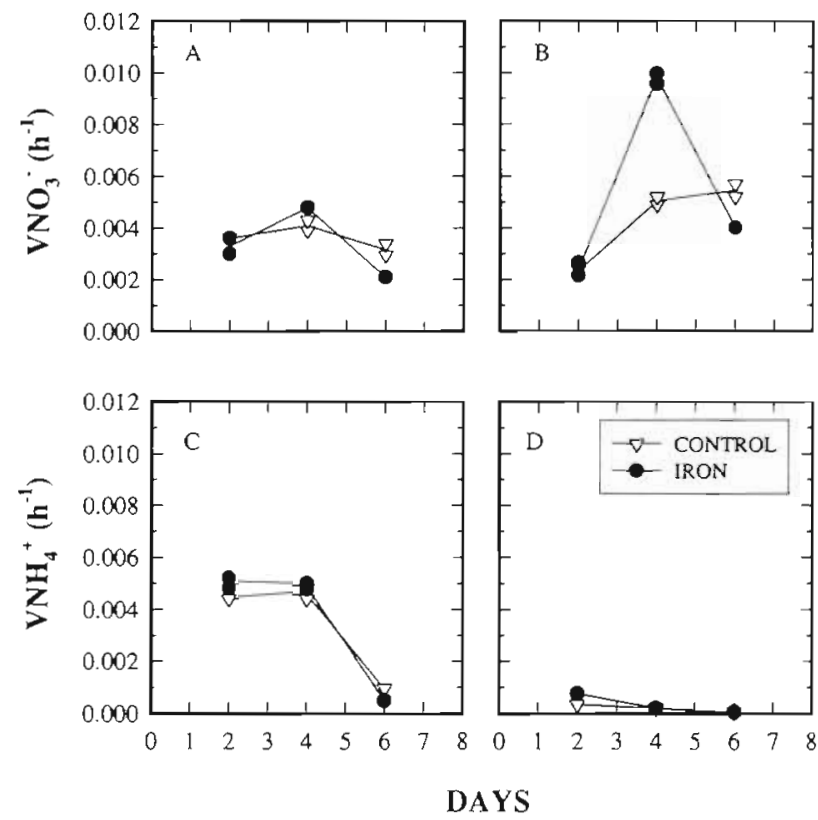

Fig. 5. Nitrogen-specific uptake rates, Expt 2 (May 1993) of nitrate $\left(\mathrm{VNO}_{3}^{-}\right.$) for: (A) $0.7-5 \mu \mathrm{m}$; (B) $>5 \mu \mathrm{m}$; and of ammonium ( $\mathrm{VNH}_{4}{ }^{+}$) for: (C) $0.7-5 \mu \mathrm{m}$; (D) $>5 \mu \mathrm{m}$ 


\section{Dissolved and particulate iron concentrations- Expts 1 and 2 (May 1993)}

DFe concentrations were measured, using the same Go-Flo, for surface samples and samples taken from the $C$ and Fe carboys during Expts 1 and 2. Ambient DFe levels of $0.35 \pm 0.07 \mathrm{nmol} \mathrm{kg}{ }^{-1}$ were measured at OSP (10 m) just prior to the onset of Expt 1, while DFe

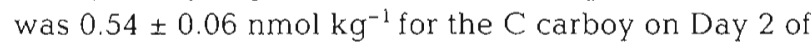
Expt 1. No samples were taken from the C carboy during the remainder of Expt 1 or during Expt 2. A decrease in DFe with time was observed during both experiments for the Fe carboys: concentrations were $1.1 \pm 0.08$ and $1.68 \pm 0.06 \mathrm{nmol} \mathrm{kg}{ }^{-1}$ on Day 2 of Expts 1 and 2 , respectively, and decreased to ca $0.8 \pm 0.06$

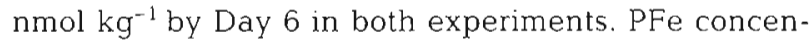
trations for the $0.2-5 \mu \mathrm{m}$ fraction in the Fe carboy in Expt 2 were high and variable ( 4 to $30 \mathrm{nmol} \mathrm{kg}{ }^{-1}$ ) suggesting variations, between samples, in the abundance of particles $>0.2 \mu \mathrm{m}$ but $<5 \mu \mathrm{m}$. In contrast, $\mathrm{PFe}$ in the $>5 \mu \mathrm{m}$ fraction was not variable, increasing with time from 2.1 to $5.7 \mathrm{nmol} \mathrm{l}^{-1}$ (Fig. 6A), presumably due to microalgal utilization of a combination of dissolved and

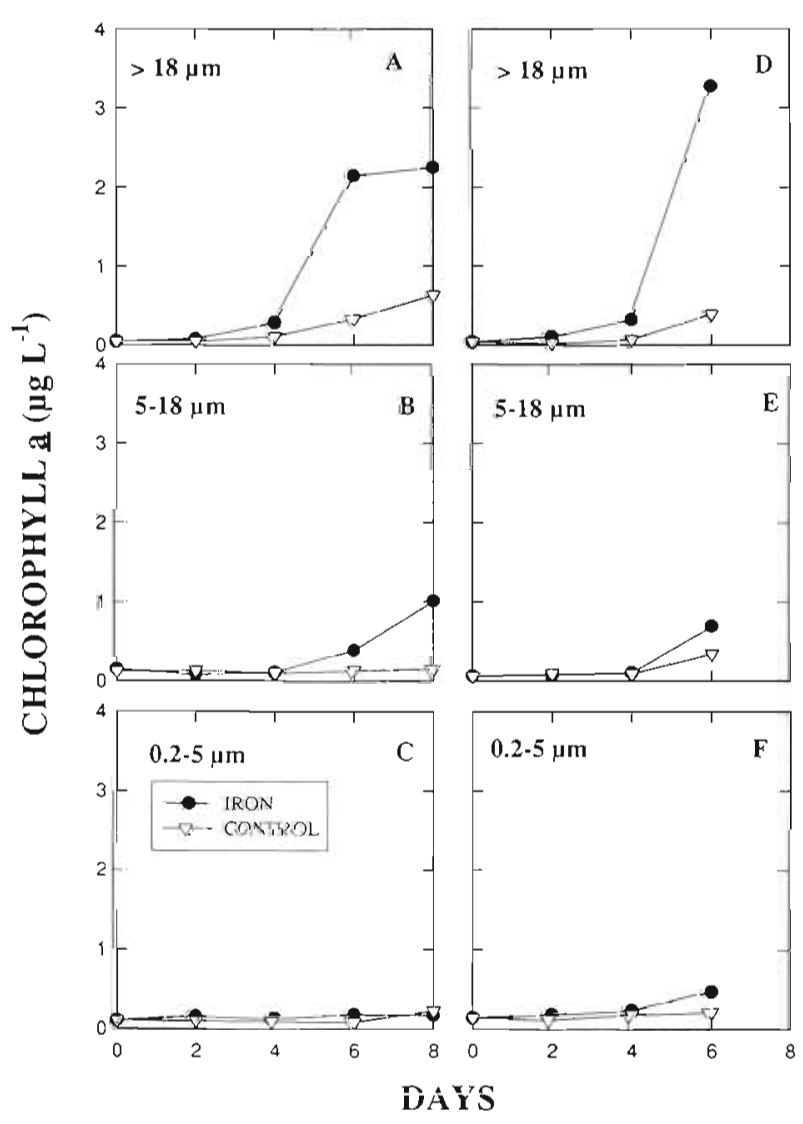

Fig. 7. Size-fractionated chl a from Expts $1(A-C)$ and $2(D-F)$ for 3 size fractions for Fe and C carboys, May 1993. No replicates
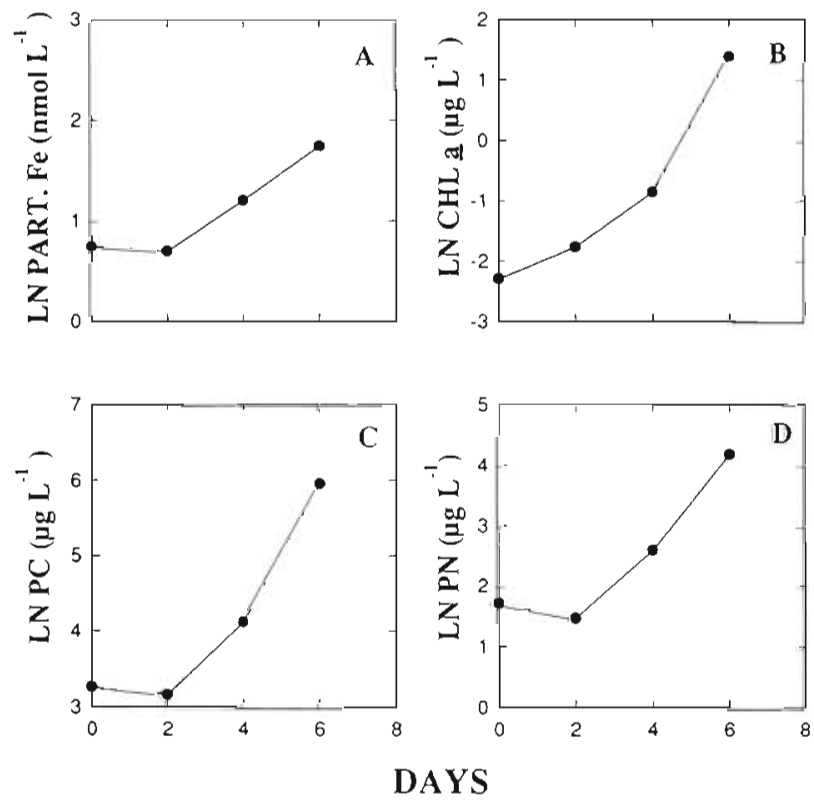

Fig. 6. Natural $\log$ of $(A)>5 \mu \mathrm{mPFe}$ (B) chl $a_{i}$ (C) PC; and (D) PN against time for Expt 2, May 1993. Values of $r^{2}$ for regressions for Days 2 to 6 between $A$ and $B, A$ and $C$ and $A$ and $D$ were $0.972,0.978$ and 0.995 , respectively $(n=3)$

remineralized $\mathrm{Fe}$. A semi-log plot of $>5 \mu \mathrm{m}$ PFe against time from the Fe carboy revealed this increase to be linear and correlated significantly with changes in chl a, PN and PC for this fraction over time (see Fig. 6 legend).

\section{Size-fractionated chl $a$ and primary production (May 1993)}

The influence of Fe supply on the partitioning of algal biomass and production within 3 classes was assessed using size fractionation. In Expts 1 and 2, large phytoplankton $(>18 \mu \mathrm{m})$, although initially rare, increased dramatically in biomass over time and accounted for $>80 \%$ of stocks by Day 6 in the Fe carboys (Fig. 7A, D). Large cells were also responsible for most of the slight increase in algal biomass in the $C$ carboy (Fig. 7A, D). The biomass of the 5-18 $\mu \mathrm{m}$ fraction showed little change in the Fe carboy until Day 4 (Fig. 7B, E) after which time there was a 2 -fold increase by Day 6 , and in Expt 1 a 4 -fold increase by day 8 (Fig. 7B). The 5-18 $\mu \mathrm{m}$ fraction showed little change in chl a with time in the C carboy (Fig. $7 \mathrm{E}$ ) and a similar lack of change was observed for the $0.2-5 \mu \mathrm{m}$ fraction in the $\mathrm{C}$ or Fe carboys for both experiments (Fig. $7 \mathrm{C}$ : F). The partitioning of primary production within each fraction in both experiments revealed similar trends to those noted for chl $a$ in the $C$ and Fe carboys. 


\section{Phytoplankton species composition-Expts 1 and 2 (May 1993)}

Microscopical counts for the main taxa indicated that diatom abundances increased dramatically in the Fe carboys $_{i}>12$-fold from initial concentrations by Day 6 in both experiments. By Day 8 in Expt 1, diatoms had increased to 50 times their initial abundance. Diatoms also dominated the assemblage in the Fe carboys in Expt 3 (May 1994). Diatom abundances increased in the $C$ carboys, with concentrations being 2 to 4 times higher by Day 6 than observed initially in Expts 1 and 2. In contrast, dinoflagellate abundances were invariant over the course of Expts 1 and 2, while $<5 \mu \mathrm{m}$ flagellates showed considerable variation in abundance in both experiments. In May 1993, pennates < $5 \mu \mathrm{m}$ in length and Nitzschia spp. $>15 \mu \mathrm{m}$ in length were the dominant diatoms, while Prorocentrum minimum and nondescriptive flagellates $<5 \mu \mathrm{m}$ dominated the dinoflagellate and nanoflagellate groups, respectively (Table 2). Nitzschia spp. $>15 \mu \mathrm{m}$ were initially rare in both experiments, but showed rapid increases in abundance in the Fe carboys and less pronounced increases in the $C$ carboys (Table 2). $P$. minimum and the $<5 \mu \mathrm{m}$ flagellates reflected the trends observed for dinoflagellate and nanoflagellate numbers.

Table 2. Abundance of the main phytoplankton species $\left(\times 10^{5}\right.$ $1^{-1}$ ) from the $C$ and Fe carboys in Expts 1 and 2, May 1993

\begin{tabular}{|c|c|c|c|c|c|}
\hline & \multicolumn{5}{|c|}{ Day } \\
\hline & 0 & 2 & 4 & 6 & 8 \\
\hline \multicolumn{6}{|l|}{ Expt 1 (Control) } \\
\hline Pennates $<5 \mu \mathrm{m}$ & 5.9 & 4.0 & 3.5 & 5.6 & 23.5 \\
\hline Nitzschia sp. $>50 \mu \mathrm{m}$ & $<0.1$ & 0.4 & 1.3 & 5.3 & 7.0 \\
\hline Nitzschia sp. $15-50 \mu \mathrm{m}$ & $<0.1$ & $<0.1$ & $<0.1$ & 0.3 & 1.6 \\
\hline Prorocentrum minimum & $<0.1$ & 0.5 & 0.4 & $<0.1$ & 1.2 \\
\hline Nanoflagellates $(<5 \mu \mathrm{m})$ & 4.1 & 1.1 & 22.1 & 3.3 & 26.5 \\
\hline \multicolumn{6}{|l|}{ Expt 1 (Iron-addition) } \\
\hline Pennates $<5 \mu \mathrm{m}$ & 4.8 & 2.4 & 5.7 & 15.2 & 141.7 \\
\hline Nitzschia sp. $>50 \mu \mathrm{m}$ & $<0.1$ & 0.5 & 1.2 & 38.4 & 83.8 \\
\hline Nitzschiasp. $15-50 \mu \mathrm{m}$ & $<0.1$ & 0.4 & 0.4 & 16.6 & 34.0 \\
\hline Prorocentrum minimum & 0.6 & 0.3 & 0.3 & 0.6 & 1.7 \\
\hline Nanoflagellates $(<5 \mu \mathrm{m})$ & 3.9 & 0.6 & 33.0 & 7.4 & 10.3 \\
\hline \multicolumn{6}{|l|}{ Expt 2 (Control) } \\
\hline Pennates $<5 \mu \mathrm{m}$ & 4.8 & 3.7 & 7.4 & 10.0 & \\
\hline Nitzschia sp. $>50 \mu \mathrm{m}$ & $<0.1$ & 0.3 & 0.1 & 0.6 & \\
\hline Nitzschia sp. $15-50 \mu \mathrm{m}$ & $<0.1$ & 0.2 & 0.8 & 2.4 & \\
\hline Prorocentrum minimum & 0.3 & 0.1 & 0.4 & 0.3 & \\
\hline Nanoflagellates $(<5 \mu \mathrm{m})$ & 2.8 & 16.1 & 22.4 & 9.3 & \\
\hline \multicolumn{6}{|l|}{ Expt 2 (Iron-addition) } \\
\hline Pennates $<5 \mu \mathrm{m}$ & 4.8 & $<0.1$ & 5.7 & 9.7 & \\
\hline Nitzschia sp. $>50 \mu \mathrm{m}$ & $<0.1$ & 0.7 & 3.2 & 40.4 & \\
\hline Nitzschia sp. $15-50 \mu \mathrm{m}$ & $<0.1$ & 0.2 & 1.1 & 10.6 & \\
\hline Prorocentrum minimum & 0.3 & 0.3 & 0.3 & 0.2 & \\
\hline Nanoflagellates $(<5 \mu \mathrm{m})$ & 2.8 & 18.6 & 40.8 & 5.0 & \\
\hline
\end{tabular}

\section{Algal growth rates - Expts 1 and 2 (May 1993)}

Phytoplankton community and sub-population net growth rates were estimated in 2 ways (Table 3 ), from the instantaneous change in: (1) phytoplankton cell numbers (Table 2) and (2) size-fractionated chl a (Table 3A) between Days 2 and 6. In Expt 1, net growth rates were significantly higher in the Fe carboy than in the $C$ carboy as estimated from total chl a, $>18 \mu \mathrm{m}$ chl $a_{1}$ 5-18 $\mu \mathrm{m}$ chl $a_{1}$ total diatoms and Nitzschia spp. $>15 \mu \mathrm{m}$. In contrast, in Expt 2, only 0.2-5 $\mu \mathrm{m}$ chl $a$ and Nitzschia spp. >50 $\mu \mathrm{m}$ (Table 3) had significantly different net growth rates between treatments. Differences in growth rates for the algal size fractions were observed in both experiments (Fig. 8). In the Fe carboy, cells $>18 \mu \mathrm{m}$ showed an increase in growth rate from almost the start of the bioassay. However, the 5-18 $\mu \mathrm{m}$ and $0.2-5 \mu \mathrm{m}$ fractions showed little change until after Day 4, and throughout the experiments, respectively.

Table 3. Net algal growth rates $\left(\mathrm{d}^{-1}\right)$ derived from the instantaneous change in: (A) total and size-fractionated $\mathrm{chl} a_{\text {i }}$ and (B) phytoplankton cell counts during Expts 1 and 2, May 1993. Linear regressions for the slopes of the lines for the $\mathrm{Fe}$ and $\mathrm{C}$ carboys were compared using Student's $t$-test. 'Statistically significant relationships between samples from Fe and $C$ carboys $(p>0.05)$

\begin{tabular}{|c|c|c|c|c|}
\hline & \multicolumn{2}{|c|}{ Control } & \multicolumn{2}{|c|}{ Iron-addition } \\
\hline & $\mu$ & $r^{2}$ & $\mu$ & \\
\hline \multicolumn{5}{|l|}{ Expt 1} \\
\hline \multicolumn{5}{|l|}{ (A) Chlorophyll } \\
\hline Total & 0.16 & 0.81 & $0.35^{\circ}$ & 0.86 \\
\hline$>18 \mu \mathrm{m}$ & 0.35 & 0.94 & $0.54^{*}$ & 0.92 \\
\hline $5-18 \mu \mathrm{m}$ & 0.02 & 0.22 & $0.27^{\bullet}$ & 0.66 \\
\hline $0.2-5 \mu \mathrm{m}$ & 0.06 & 0.24 & 0.05 & 0.58 \\
\hline \multicolumn{5}{|l|}{ (B) Cell counts } \\
\hline Diatoms & 0.25 & 0.71 & $0.55^{*}$ & 0.85 \\
\hline Nanoflagellates & 0.17 & 0.19 & 0.14 & 0.14 \\
\hline Dinoflagellates & -0.05 & 0.01 & 0.15 & 0.45 \\
\hline Pennates $<5 \mu \mathrm{m}$ & 0.16 & 0.41 & 0.43 & 0.74 \\
\hline Nitzschia spp. $>50 \mu \mathrm{m}$ & 0.55 & 0.96 & $0.89^{*}$ & 0.98 \\
\hline Nitzschia spp. 15-50 $\mu \mathrm{m}$ & 0.33 & 0.74 & $0.77^{*}$ & 0.88 \\
\hline \multirow{2}{*}{\multicolumn{5}{|c|}{$\begin{array}{l}\text { Expt } 2 \\
\text { (A) Chlorophyll }\end{array}$}} \\
\hline & & & & \\
\hline Total & 0.22 & 0.85 & 0.47 & 0.88 \\
\hline$>18 \mu \mathrm{m}$ & 0.53 & 0.67 & 0.72 & 0.94 \\
\hline $5-1.8 \mu \mathrm{m}$ & 0.26 & 0.79 & 0.38 & 0.77 \\
\hline $0.2-5 \mu \mathrm{m}$ & 0.08 & 0.71 & $0.19^{*}$ & 0.92 \\
\hline \multicolumn{5}{|l|}{ (B) Cell counts } \\
\hline Diatoms & 0.26 & 0.86 & 0.46 & 0.64 \\
\hline Nanoflagellates & 0.11 & 0.18 & 0.06 & 0.03 \\
\hline Dinoflagellates & -0.01 & 0.00 & -0.09 & 0.29 \\
\hline Pennates $<5 \mu \mathrm{m}$ & 0.24 & 0.71 & 0.19 & 0.25 \\
\hline Nitzschia spp. $>50 \mu \mathrm{m}$ & 0.21 & 0.38 & $0.96^{\bullet}$ & 0.98 \\
\hline Nitzschia spp. 15-50 $\mu \mathrm{m}$ & 0.55 & 0.98 & 0.78 & 0.94 \\
\hline
\end{tabular}




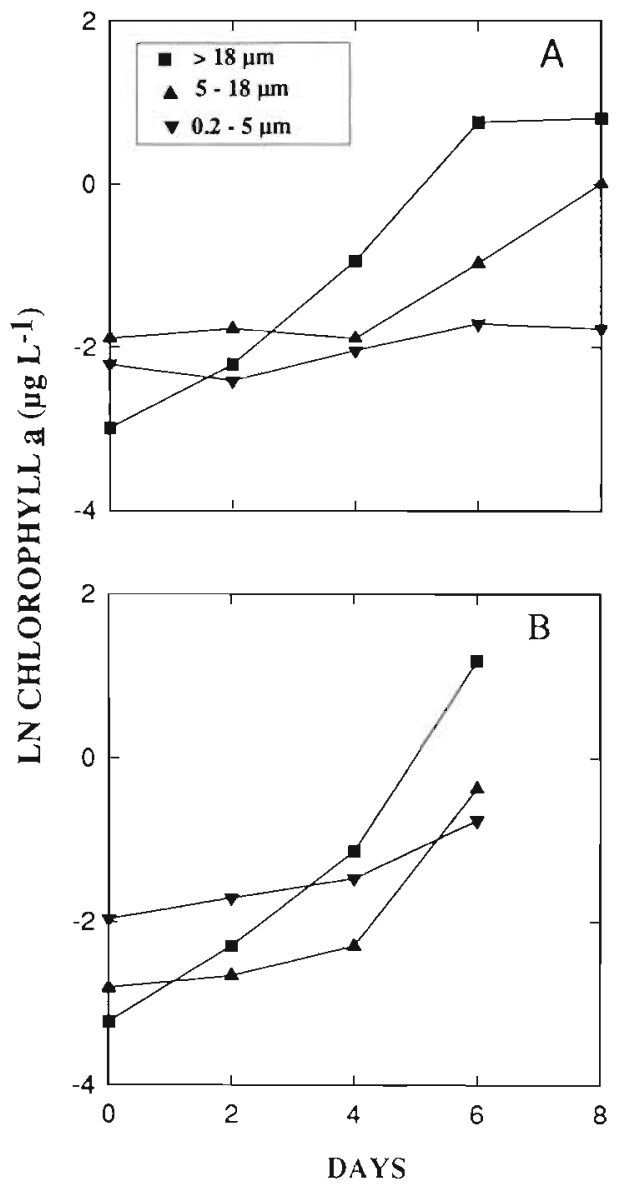

Fig. 8. Natural log of chl a for 3 size fractions from the Fe carboy during the course of (A) Expt 1 and (B) Expt 2, May 1993. No replicates

\section{Biochemical composition of laboratory cultured phytoplankton}

Comparable $C: N$ ratios $(11.0 ; 8.2)$, and markedly different C:Fe ratios (50000; 19000), were derived from laboratory studies using Emiliania huxleyi (95\% $\left.\mu_{\max }\right)$ and Actinocyclus sp. $\left(65 \% \mu_{\max }\right)$, respectively. C:N and $\mathrm{C}$ :Fe ratios of 6.8 and 13000 were observed under Fereplete conditions $\left(95 \% \mu_{\max }\right)$ for Actinocyclus sp. These ratios were used to calculate algal Fe requirements in the $\mathrm{C}$ and $\mathrm{Fe}$ carboys (Table 4). A comparison of the molar ratios for the $>5 \mu \mathrm{m}$ fraction from the $\mathrm{Fe}$ carboy during Expt 2 with those from the laboratory cultured diatom indicated that at $\mathrm{t}=0$, the $\mathrm{Fe}: \mathrm{C}$ and $\mathrm{Fe}: \mathrm{N}$ ratios were greater than the lower limit for $\mathrm{Fe}$ replete values of Actinocyclus sp. (Table 5); however the high PFe value from OSP for $\mathrm{t}=0$, which was probably due to contamination, may have artificially increased this ratio. On Days 2 to 4 in the Fe carboy, the $\mathrm{Fe}: \mathrm{C}$ and $\mathrm{Fe}: \mathrm{N}$ ratios were comparable to the Fereplete range for Actinocyclus sp. (Table 5). However,
Table 4. Calculated algal Fe requirements (nM) in the $C$ and Fe carboys (May 1993) based on: (A) chl a, C:Fe ratios of 33000 (Martin et al. 1989) and C:chl a ratios of 50 (Booth et al. $1993)$ and $(B)$ the disappearance of nitrate and $C: N$ ratios of (1) 6.6 (Redfield 1958), and C:Fe ratios of 33000 (Martin et al. 1989) (2) 11.0 and 50000 derived from Emiliania huxleyi (lab culture) (3) 8.2/6.8 and 19000/13000 derived from Actinocyclus sp. (lab culture) for Fe-deplete and replete, respectively

\begin{tabular}{|lccccc|}
\hline \multirow{2}{*}{ Calculation } & \multicolumn{2}{c}{ Expt 1 } & \multicolumn{2}{c|}{ Expt 2 } \\
& C & Fe & C & Fe \\
\hline (A) & 0.11 & 0.44 & 0.11 & 0.52 \\
(B) $(1)$ & 0.80 & 1.71 & 0.92 & 1.61 \\
& $(2)$ & 0.18 & 0.38 & 0.21 & 0.37 \\
& (3) & 1.30 & 3.90 & 1.30 & 3.80 \\
\hline
\end{tabular}

Table 5. Comparison of calculated molar ratios from $>5 \mu \mathrm{m}$ fraction from the Fe carboy during Expt 2 (May 1993) and values from Actinocyclus sp. (growing at $95 \% \mu_{\max }$ ). PFe, used to estimate $\mathrm{C}: \mathrm{Fe}$ and $\mathrm{N}: \mathrm{Fe}$ ratios for the $>5 \mu \mathrm{m}$ fraction, may include extracellularly bound $\mathrm{Fe}$. C and $\mathrm{N}$ data for the $>5 \mu \mathrm{m}$ cells were obtained from direct measurements (see Fig. 6)

\begin{tabular}{|cccc|}
\hline & $\begin{array}{c}\text { Fe:C } \\
(\mu \mathrm{mol}: \mathrm{mol})\end{array}$ & $\begin{array}{c}\text { Fe: } \mathrm{N} \\
(\mu \mathrm{mol}: \mathrm{mol})\end{array}$ & $\begin{array}{c}\mathrm{C}: \mathrm{N} \\
(\mathrm{mol}: \mathrm{mol})\end{array}$ \\
\hline Time $(\mathrm{d})$ & & & \\
0 & 960 & 5360 & 5.6 \\
2 & 1050 & 6500 & 6.2 \\
4 & 650 & 3500 & 5.4 \\
6 & 180 & 1200 & 6.7 \\
Actinocyclus sp. & & & \\
Fe-replete: & $>200$ & $>1400$ & $<6.8$ \\
\hline
\end{tabular}

by Day 6 Fe:C and Fe: $N$ ratios decreased and were less than the lower limit for Actinocyclus sp. Fe-replete values.

\section{Microzooplankton herbivory-Expt 1 (May 1993)}

Regression analysis of the data-sets (Fig. 9) indicated that linear regression techniques (Landry \& Hassett 1982) provided the most significant, and thus appropriate, fit for all data. Specific algal growth rates $(\mu)$ were always greater than grazing mortality $(g)$, and $g / \mu$ was ca 0.6 to 0.7 between the onset and Day 4 of the experiment, suggesting a limited degree of coupling between growth and grazing (Table 6). However, there was no statistical difference (Student's $t$-test) between rates of $\mu$ and $g$ in each carboy for experiments carried out at $\mathrm{t}=0$, Day 2 and Day 4 (C carboy only). On Day 4 in the Fe carbny, 13 was statistically higher than $g$. On Day 6 , while nitrate in the Fe carboy was $<1 \mu \mathrm{M}$ and potentially limited growth, $\mu$ was significantly higher than $g$ in both carboys 
Table 6. Phytoplankton specific growth rates $(\mu)$ and grazing mortality $(g)$ from microzooplankton dilution experiments (Expt 1, May 1993), g/ $\mu$ = ratio of grazing:algal growth $\pm 1 \mathrm{SE}$

\begin{tabular}{|lccccc|}
\hline Expt & Day & $\begin{array}{c}\text { Specific } \\
\text { algal growth } \\
\mu\left(\mathrm{d}^{-1}\right)\end{array}$ & $\begin{array}{c}\text { Grazing } \\
\text { mortality } \\
g\left(\mathrm{~d}^{-1}\right)\end{array}$ & $\begin{array}{c}\text { Net algal } \\
\text { growth } \\
\text { rates }\end{array}$ & $g / \mu$ \\
\hline Initial & 0 & $0.51 \pm 0.15$ & $0.36 \pm 0.17$ & 0.15 & $0.71 \pm 0.25$ \\
Control & 2 & $0.49 \pm 0.20$ & $0.30 \pm 0.22$ & 0.19 & $0.61 \pm 0.30$ \\
& 4 & $0.62 \pm 0.14$ & $0.43 \pm 0.15$ & 0.19 & $0.69 \pm 0.26$ \\
& 6 & $0.64 \pm 0.10$ & $0.26 \pm 0.12$ & 0.38 & $0.41 \pm 0.15$ \\
Iron-addition & 2 & $0.57 \pm 0.26$ & $0.33 \pm 0.29$ & 0.24 & $0.58 \pm 0.35$ \\
& 4 & $1.38 \pm 0.32$ & $0.80 \pm 0.40$ & 0.58 & $0.58 \pm 0.44$ \\
& 6 & $0.76 \pm 0.13$ & $0.41 \pm 0.15$ & 0.35 & $0.54 \pm 0.20$ \\
\hline
\end{tabular}

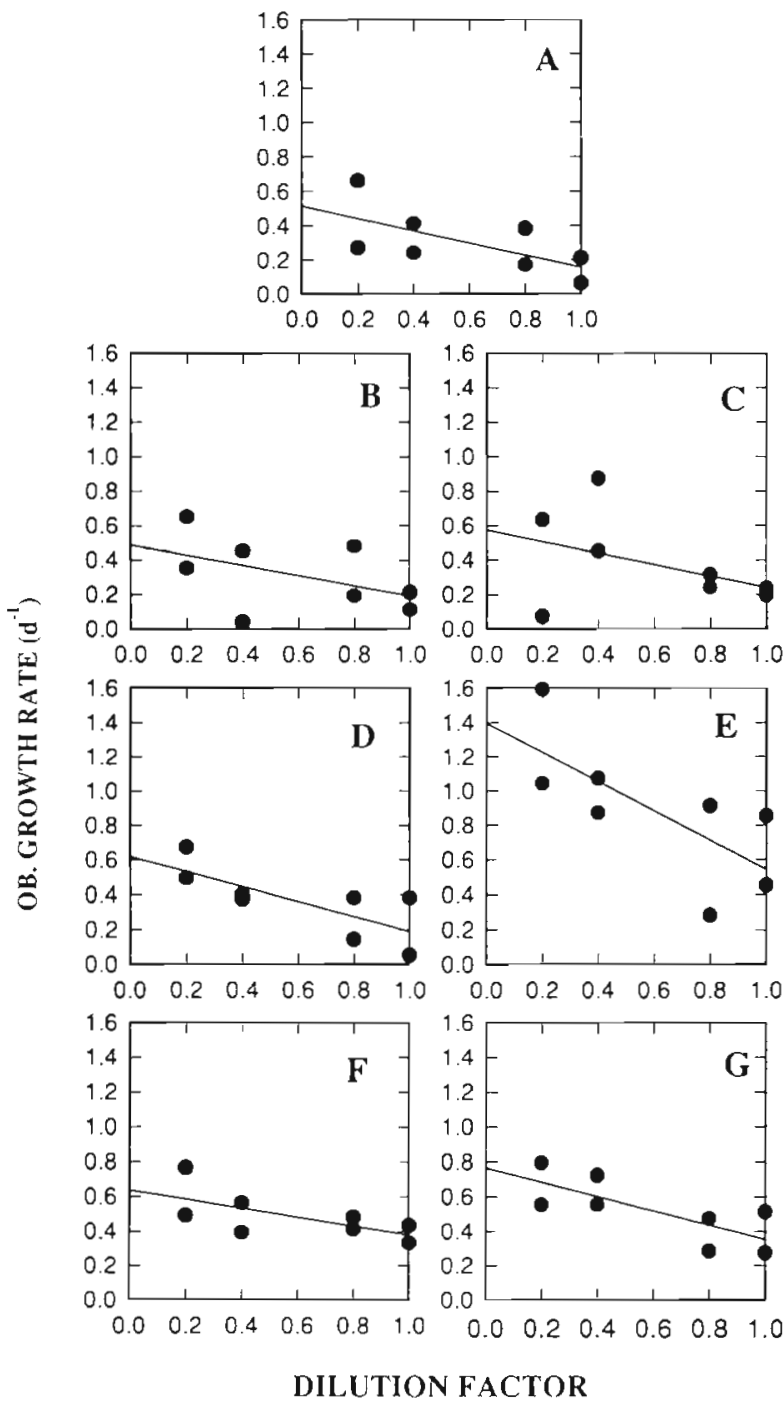

Fig. 9. Results from microzooplankton grazing, Expt 1, May 1993, from: (A) $t=0 ;(B) t=2 d$ control, (C) $t=2 d, 2 n M F e$ added; (D) $t=4 d_{\text {, control }}(E) t=4 d_{1} 2 \mathrm{nM} \mathrm{Fe}_{i}(\mathrm{~F}) \mathrm{t}=6 \mathrm{~d}$, controli $_{(}(\mathrm{G}) \mathrm{t}=6 \mathrm{~d}, 2 \mathrm{nM}$ Fe. Phytoplankton specific growth and grazing rates were estimated from a linear regression fit to the data

\section{Mesozooplankton herbivory - Expt 3 (May 1994)}

Rates of herbivory, based on filtration rates for ambient chl $a$, of $0.016 \mu \mathrm{g} c h l$ a $\mathrm{l}^{-1} \mathrm{~d}^{-1}$ were estimated for the duration of Expt 3. Calculated maximum ingestion rates, in response to elevated phytoplankton concentrations such as observed on

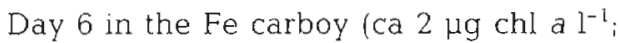
Fig 2C), were $0.86 \mu \mathrm{g} \mathrm{chl}$ a cop. $\mathrm{cos}^{-1} \mathrm{~d}^{-1}$ There were 0.24 Neocalanus spp. $1^{-1}$ in each carboy (Table 1) giving an ingestion

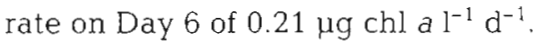

\section{DISCUSSION}

\section{Comparison with other NE subarctic Pacific studies}

Results obtained from this study may be compared with both observational data from the SUPER Program in May/June (such as Booth et al. 1993) and the findings from Fe-enrichment experiments conducted in late summer (including Coale 1991), in order to assess interannual variability in ambient conditions and any seasonal trends in the role of Fe enrichment, respectively. The community at OSP and the magnitude of their specific algal growth rates, at the onset of the experiments in the present study was similar to that observed by Booth ef al. $(1988,1993)$, with cells $<5 \mu \mathrm{m}$ dominating the assemblage and growing at close to their theoretical maximum at ambient temperatures (ca $0.55 \mathrm{~d}^{-1}$ ). Data on grazers obtained in the present study also concurred with previous observations; rates of $\mu$ and $g$ from May 1993 dilution experiments at $t=0$, were within the range observed at OSP in late spring (Landry et al. 1993b). Also, mesozooplankton abundances in net hauls taken in May 1993 and May 1994 were comparable to those observed at OSP in May/ June in other years by Dagg (1993a), and thus similar to those reported by Fulton (1978) who noted the highest annual pelagic abundances during this period. Despite compositional differences between the mesozooplankton in the carboys and those collected in the hauls in the present study, data on species-specific grazing rates in May/June at OSP (Dagg 1993a) indicate that the grazing rates of Neocalanus flemingeri are similar to those observed for $N$. plumchrus. Estimates of herbivory in the carboys in May 1994 are therefore likely to be representative of in situ rates, and indicate that these grazers may consume ca $7 \%$ of algal standing stocks per day. This compares favorably with grazing rates from modeling approaches (Frost 1987). 
Ambient DFe concentrations measured in surface waters at OSP in May 1993 were ca 6-fold higher than observed in August at OSP by Martin et al. (1989). Due to the small observational dataset for this region (Martin et al. 1989, present study), evidence of pronounced seasonality in mineral aerosol deposition over the N Pacific (Uematsu et al. 1983), and the problems in carrying out procedural blanks for shipboard trace metal sampling, it is difficult to ascertain if these differences in ambient concentration are due to interannual variability and/or contamination. It may be noted that the procedural blanks for the laboratory organic extractions in the present study were within the range reported by Martin et al. (1989). In addition, in May 1993, at an open ocean station (P20) $200 \mathrm{~km}$ due east of OSP, DFe concentrations of $0.18 \pm 0.06$

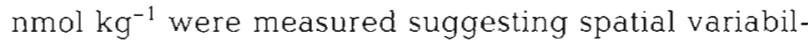
ity in DFe levels in this region. Bruland et al. (1994), in the central North Pacific, indicate the likelihood of interannual variability in DFe levels in the upper water column.

The trends of pronounced increases in algal biomass in the Fe carboys relative to those in the C carboys concur with those reported by Martin et al. (1989) and Coale (1991). Initial rates of primary production (Fig. 3) were comparable to those reported by Martin et al. (1989) and Coale (1991), and elevated rates of production, relative to $t=0$, were noted in Expts 1 and 2, and by Coale (1991). In contrast to Coale (1991), lower initial photosynthetic assimilation ratios were estimated in May 1993. However, in Expts 1 and 2 the ratios generally increased over time suggesting healthy in vitro populations, whereas Coale (1991) reported decreases in the ratio, interpreted by Banse (1991a) as evidence of unhealthy conditions for the cells. In Expt 1, the ratio declined in the Fe carboy only after Day 6 , and at this time nitrate was $<1 \mu \mathrm{M}$, suggesting $N$ limitation in the absence of any other $N$ sources (Eppley et al. 1969).

The general agreement between the findings in $\mathrm{Fe}$ enrichment studies in May and August was confirmed by the observed Fe-mediated floristic shifts. During May 1993, Fe-enrichment promoted large increases in the abundances of Nitzschia spp. $>15 \mu \mathrm{m}$ in length, but little change in the abundance of the main dinoflagellate Prorocentrum minimum over time. The former observation concurs with Martin et al. (1989), while the latter was reported by Coale (1991). Size-fractionated primary production (not shown) data indicate that cells $>18 \mu \mathrm{m}$ were responsible for $>80 \%$ of production in the Fe carboy, whereas Coale (1991) reported that the $>25 \mu \mathrm{m}$ fraction was responsible for ca $30 \%$ of production in an rie carboy. These differences in the relative importance of large cells may be due to the different size fractions employed or to sampling different 'seed' populations of Fe-limited cells.
In the present study, nanoflagellates, initially dominant and probably growing at close to their maximal rates (Booth et al. 1988, present study), had low net growth rates with little difference between the $\mathrm{C}$ and Fe carboys. They also displayed dramatic fluctuations in abundance over $2 \mathrm{~d}$ periods, analogous to those predicted by Lotka-Volterra predator-prey oscillations. These observations suggested a close coupling between these cells and microzooplankton and/or no elevated growth rates due to Fe supply. These estimated net growth rates (Table 3 ) were within the reported range for these taxa observed in May at OSP (Landry et al. 1993b). In May 1993, there was no significant change in $g$ between that observed at $t=0$ and for the remainder of the experiment in both carboys suggesting that grazers remained healthy throughout the experiment. The lack of statistical difference between $\mu$ and $g$ observed up until Day 4 in the $C$ and Fe carboys suggests that microzooplankton grazing and algal growth were coupled over this time. However, the magnitude of this coupling (ca 0.6 to 0.7 ) is less than that reported by Frost (1991) who predicted from mass balance calculations that the finite grazing loss must be ca $80 \%$ of the specific growth rate.

\section{Comparison with other HNLC regions}

This study presents the first report of Fe-induced shifts in the partitioning of $\mathrm{N}$ uptake between size fractions at OSP, and therefore concurs with the experiments of Price et al. $(1991,1994)$ who noted that Fe supply stimulated the uptake of nitrate over ammonium for cells $>5 \mu \mathrm{m}$ in the Equatorial Pacific. In May 1993, the increase of $\mathrm{VNO}_{3}{ }^{-}$in the Fe carboy indicated a physiological response by cells $>5 \mu \mathrm{m}$ to Fe enrichment, however by Day $6, \mathrm{VNO}_{3}{ }^{-}$by large cells in the $\mathrm{Fe}$ carboy decreased, probably due to the onset of nitrate or Fe limitation. In contrast, and as noted by Price et al. (1991), no change in $\mathrm{VNO}_{3}{ }^{-}$was observed over time in the Fe carboy by cells $<5 \mu \mathrm{m}$. The increase in $\mathrm{VNO}_{3}{ }^{-}$ between Days 2 and 4 by cells $>5 \mu \mathrm{m}$ in the $\mathrm{C}$ carboy (Fig. $5 \mathrm{~B}$ ) was similar to changes observed in both the size fractionated-biomass and primary production in the controls of Expts 1 and 2. However, as no DFe measurements were made in the C carboy in Expt 2, it is not possible to resolve whether inadvertent Fe contamination was responsible for the observed increase in $\mathrm{VNO}_{3}{ }^{-}$at this time. There was little change in $\mathrm{VNH}_{4}{ }^{+}$in either size fraction or treatment (Fig. 5C, D). A decrease in $\mathrm{VNH}_{4}{ }^{+}$between Days 4 and 6 in both treatmonts for colls $<5$ um was likely due to the exhaustion of added ${ }^{15} \mathrm{~N}$ by phytoplankton during the $24 \mathrm{~h}$ incubation; $\mathrm{N}$ dynamics may have been perturbed as ammonium had decreased to $<0.05 \mu \mathrm{M}$ by Day 6 . During the 
$6 \mathrm{~d}$ experiment, in both the $\mathrm{C}$ and Fe carboys,ammonium was taken up ca $90 \%$ faster by cells $<5 \mu \mathrm{m}$, compared to those $>5 \mu \mathrm{m}$. Price et al. (1994) also found evidence of small cells primarily utilizing ammonium as a $N$ source in the Equatorial Pacific. Despite ammonium levels of 0.2 to $0.3 \mu \mathrm{M}$ on Day 4 for the $\mathrm{C}$ and $\mathrm{Fe}$ carboys, $\mathrm{VNO}_{3}-$ was enhanced at this time. This observation, albeit for cells $>5 \mu \mathrm{m}$, appears to contradict Wheeler \& Kokkinakis (1990), who concluded that ammonium concentrations of 0.1 to $0.3 \mu \mathrm{M}$ suppress nitrate uptake at OSP.

\section{In vitro Fe dynamics - Expts 1 and 2 (May 1993)}

DFe in the Fe carboy on Day 2 in both experiments were less than the calculated initial concentration of $2 \mathrm{nM}$, indicating either algal Fe uptake or adsorption of $\mathrm{Fe}$ onto the carboy walls and/or detritus (see Hutchins et al. 1993). Although significant adsorption to the walls is unlikely due to preconditioning the carboys for $36 \mathrm{~h}$, a slight reduction in DFe of ca $0.25 \mathrm{nM}$ in the Fe carboys was possible. This estimate was based on the study of Martin et al. (1989) who reported that adsorption of added $\mathrm{Fe}$ to container walls accounted for $<20 \%$ of Fe. DFe in the Fe carboys decreased slightly over time suggesting microalgal uptake of DFe. However on Day 6, DFe in both experiments was $>0.8 \mathrm{nM}$ indicating that not all DFe had been utilized and was possibly in a non-bioavailable form, or that contamination during subsampling had elevated the final Fe levels. Coale (1991) measured changes in total DFe (initial + addition) during a similar experiment, and reported 2 -fold increases in an Fe carboy over time. PFe concentrations for the $>5 \mu \mathrm{m}$ fraction at $t=0$ (Expt 2) were 4 -fold higher than noted by Martin et al. (1989) and probably resulted from contamination. The change in DFe during Expts 1 and 2, do not fully account for the concurrent increases in PFe in the $>5 \mu \mathrm{m}$ fraction. The probable reason for this discrepancy is that PFe in the 0.2-5.0 $\mu \mathrm{m}$ fraction was unknown and may have existed in bioavailable forms. Smaller contributions of Fe could have been derived from leaching from the carboy walls, or from Fe recycling from phytoplankton $<5 \mu \mathrm{m}$ by cell lysis or grazing (see Hutchins et al. 1993).

Increases in PFe $(>5 \mu \mathrm{m})$ with time was correlated significantly with concurrent changes in chlorophyll, PC and PN (Fig. 7), and were probably biologically mediated. During Expt 2, a comparison of the molar ratios (Fe: $\mathrm{C}$ and Fe:N) for cells $>5 \mu \mathrm{m}$ with Actinocyclus sp. indicate that phytoplankton were Fe-replete between Days 2 and 4, but that by Day 6 cells may have been Fe-stressed in the Fe carboy (Table 5). A budget of potential Fe utilization based on observed changes in nitrate (gross Fe utilization) and chl a (net $\mathrm{Fe}$ utilization), and $\mathrm{C}: \mathrm{N}, \mathrm{C}: \mathrm{Fe}$ and $\mathrm{C}: \mathrm{chl} a$ ratios obtained both from the literature and culture studies was constructed (Table 4). As expected, calculated Fe requirements based on chl a accumulation were less than those estimated from nitrate disappearance. Between Days 2 and 6, observed changes in DFe in the Fe carboys in Expts 1 and 2 were $>0.2$ and $>0.78 \mathrm{nM}$, respectively. The calculated net $\mathrm{Fe}$ requirements based on chl a (Table $4 \mathrm{~A}$ ) were too low to explain the changes in DFe in the Fe carboy during Expt 2. while those estimates based on nitrate (Table $4 \mathrm{~B}$ ) were too high to explain changes in $\mathrm{DFe}$ in either experiments for the Fe carboys. DFe in the C carboy $(0.54 \pm 0.06)$ on Day 2 of Expt 1 was sufficient to meet the Fe requirements based on chl $a$ in the $C$ carboy for both experiments (Table $4 \mathrm{~A}$ ) but insufficient to meet those based on nitrate for the $\mathrm{C}$ carboy (Table $4 \mathrm{~B}$ ).

Estimates of Fe requirements using pubiished ratios were intermediate with respect to those obtained from ratios derived from laboratory culture studies; the C:Fe ratios for Actinocyclus sp. were considerably lower than the ratios obtained by Sunda et al. (1991) for a diatom isolated from the Sargasso Sea and maintained under conditions (such as high EDTA levels) likely very different to those at OSP. The calculated $\mathrm{Fe}$ required by cells in the carboys, using values for the small phytoplankton, were around 8 times less than for the large phytoplankter (Table 4B), given the same amount of nitrate depletion. These inter-species differences in Fe requirements concur with the recommendations of Wells et al. (1995) for more information about the indigenous phytoplankton assemblage along with their biochemical ratios in order to accurately estimate Fe budgets in the field. The scenario which demanded the highest Fe requirement was when large cells were responsible for all of the nitrate utilization, giving an Fe requirement of $3.9 \mathrm{nmol} \mathrm{kg}{ }^{-1}$.

\section{Interpretation of in vitro experiments}

Assuming that similar environmental conditions existed in May 1993 and 1994 at OSP, the joint findings of Expts 1 to 3 permit the interpretation of in vitro $\mathrm{Fe}$ fertilization experiments and further assessment of the functioning of the pelagic ecosystem in this region. Data from $t=0$ in these experiments are indicative of ambient conditions at OSP and reveal that the autotrophs are dominated by cells $<5 \mu \mathrm{m}$ which compose $>70 \%$ of community biomass and production (Figs. 7 \& 8), with large cells such as diatoms making up a small proportion of the community. It has been assumed that apparent algal growth rates from microzooplankton herbivory experiments conducted at $\mathrm{t}=0$ 
(Table 6) primarily reflect the physiological status of these small cells. If this is so, then the dominant cells are growing at close to maximal rates under ambient conditions. In addition, these cells are primarily utilizing ammonium rather than nitrate. While the growth rates of these small cells are only moderately coupled to microzooplankton grazing mortality $(g / \mu=0.71 \pm$ 0.25), and are lower than predicted by Frost (1991) from modeling studies, they are within the range observed under ambient conditions by Landry et al. (1993b) at OSP. A close coupling with microzooplankton grazing is also consistent with high apparent growth rates (Table 6) but low observed net growth rates for these small cells (Table 3 ). These findings concur with the observations of Miller et al. (1991) and Booth et al. $(1988,1993)$ who consistently found that the resident phytoplankton at OSP were growing as fast as temperature and available light would allow.

Although the growth rates of the large diatoms, under ambient conditions, were not estimated, they were constrained from rates of mesozooplankton herbivory. At the grazing rates estimated from the May 1994 study, the $>18 \mu \mathrm{m}$ phytoplankton must have been growing at less than maximal rates $\left(0.40 \mathrm{~d}^{-1}\right)$, otherwise they would potentially escape grazing pressure. The growth rates of large cells may be lower still: others (Frost et al. 1983, Dagg 1993b) have demonstrated that Neocalanus cristatus and $N$. plumchrus are capable of removing relatively small particles from suspension and may therefore graze on phytoplankton $<18 \mu \mathrm{m}$. If cells $<18 \mu \mathrm{m}$ were included in this calculation, mesozooplankton would probably graze $<30 \%$ of large phytoplankton per day resulting in growth rates of the large cells being considerably less than $0.40 \mathrm{~d}^{-1}$; rates of this order were observed for large $(>18 \mu \mathrm{m})$ cells in the C carboy during Expt 1 . In addition, Muggli (unpubl. data) reports that the growth rates of Actinocyclus sp. under 'no $\mathrm{Fe}^{\prime}$ culture conditions are ca $0.35 \mathrm{~d}^{-1}$. Although there is no direct proof, large cells are probably utilizing nitrate as opposed to ammonium (see $t=2$ d, Fig. 5B) under ambient conditions at OSP, and the cultured representative has a relatively high Fe quota (see 'Results'). These observations appear to concur with the observations of Cullen (1991) and Frost (1991) that grazing keeps pace with algal cell division only because specific growth rates of the phytoplankton are reduced because of Fe limitation.

Upon the supply of $F e$, there was a pronounced increase in the biomass and production of the large cells and increases in net growth rate, $\mathrm{VNO}_{3}{ }^{-}$and photosynthetic assimilation ratios which are intrinsic measurements independent of grazing pressure. In contrast, the small cells exhibited no increase in $\mathrm{VNH}_{4}{ }^{+}$or $\mathrm{VNO}_{3}{ }^{-}$in response to Fe supply, showed little change in biomass, production and growth rates, and net growth rates remained low consistent with microzooplankton herbivory being the main control over the small cells. These findings are supported by observations for the cultured representative of this $<5 \mu \mathrm{m}$ fraction, which has a relatively low Fe quota (see 'Results') and shows no evidence of enhanced growth rates upon Fe supply (Muggli unpubl. data).

As observed in the Equatorial Pacific by Fryxell \& Kaczmarska (1994), the (net) growth rates of the large cells increased almost immediately (Fig. 8), and by Day 4 they had molar ratios indicative of Fe-replete conditions. The net growth rates observed in the Fe carboy ranged from $<0.1 \mathrm{~d}^{-1}$ for non-diatom taxa to $0.96 \mathrm{~d}^{-1}$ for diatom spp. (Table 3 ). These rates for Nitzschia spp. 15-50 $\mu \mathrm{m}$ and $>18 \mu \mathrm{m}$ chl a were close to the theoretical maximum at this temperature (Eppley 1972) suggesting that the influence of grazing in the carboys on these large cells was low. The growth rate for Nitzschia spp. $>50 \mu \mathrm{m}$ was ca $0.85 \mathrm{~d}^{-1}$ for the Fe carboys in Expts 1 and 2 and was higher than the maximal growth rate at $10^{\circ} \mathrm{C}$ (Eppley 1972). Banse (1991b) suggested that estimated growth rates greater than Eppley's maximum may be due to a slightly downwards biased initial datum point. This may occur particularly when cells, such as large diatoms, are initially relatively rare.

Escape of large cells from grazing pressure in the Fe carboys is borne out from the results of micro- and mesozooplanton herbivory experiments. On Day 4 in the microzooplankton experiments, a decoupling between growth and grazing was observed (Table 6). This was probably due to the rapid increase in the abundance of large phytoplankton observed in the Fe carboy which were probably too large to be preyed on at a high rate by microzooplankton. This explanation concurs with the findings of a species-specific study at OSP by Strom \& Welschmeyer (1991). Estimates of mesozooplankton herbivory (see 'Results') indicate that they are insufficient to keep phytoplankton under grazer control at Fe-induced elevated growth rates. The estimated maximum ingestion rate on Day 6 of

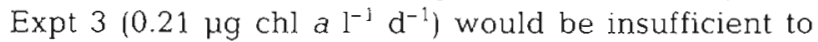
graze down stocks of the large phytoplankton since their growth rate (at $2 \mu \mathrm{g}$ chl a $\mathrm{l}^{-1}$ ) was $0.52 \mathrm{~d}^{-1}$ suggesting that chl a increased by ca $1 \mu \mathrm{g} \mathrm{l}^{-1} \mathrm{~d}^{-1}$. Landry et al. (1993a) in a 5 d grazing experiment at OSP also demonstrated that phytoplankton were able to escape grazing control at ambient mesozooplankton concentrations, but unfortunately performed no DFe mesurements. The magnitude of the grazing rates from May 1994 , at a time when the annual maximum numbers of mesozooplankton are present in the upper water column, suggest that $\mathrm{Fe}$ supply to large phytoplankton in late summer when animals are present in rela- 
tively low numbers would have a more pronounced effect.

In the controls, there is evidence, albeit from one measurement, that DFe levels in the $\mathrm{C}$ carboy on Day 2 were significantly higher than ambient DFe at OSP, suggesting contamination. This is the probable cause of the increase in algal biomass above ambient levels in the $\mathrm{C}$ carboys ( $\mathrm{Fig} 2$ ). Further evidence comes from the observation that the main increase was in large cells, observed in Fe carboy to be the main component of the population stimulated by Fe supply (Fig. 7). In addition, the demonstration of in vitro representation of mesozooplankton indicates that there was probably no artificial alleviation of grazing pressure, 1 of 2 alternative explanations for increase of biomass in the controls offered by Cullen (1991). Stoichiometric calculations using $\mathrm{C}: \mathrm{N}$ and $\mathrm{C}: \mathrm{Fe}$ ratios (Table 4 ) suggest that in the absence of recycling and/or adsorption of $\mathrm{Fe}$, the observed incrcases in diatom abundance in the $\mathrm{C}$ carboy required between 0.11 and $1.3 \mathrm{nM}$ of iron ambi-

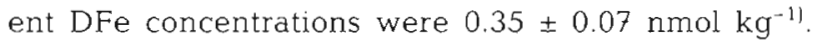
Increases in algal biomass of the same order of magnitude have been observed in the $C$ carboys of all other Fe enrichment experiments (for example see Martin et al. 1989). However since few other investigators have directly measured DFe in the C carboys (Coale 1991), it is not possible to ascertain whether these increases were iron-induced.

Acknowledgements. We thank H. Nicolidakis and B. McKelvey for technical assistance, J. Ramirez for phytoplankton cell counts, S. Doherty, H. MacLean, J. Powlik, M. Wen and F. Whitney for assistance at sea and M. Soon for PN and PC determinations. We are grateful for the insights and comments provided by $C$. Hurd and 3 anonymous reviewers. D.L.M. and D.E.V. were supported by UBC University Graduate Fellowships. This work is dedicated to J. H. Martin. This research was performed as part of the Canadian JGOFS Program. Principal support for Canadian JGOFS comes from the Natural Sciences and Engineering Research Council and from the Department of Fisheries and Oceans, Canada.

\section{LITERATURE CITED}

Banse K (1991a) Iron availability, nitrate uptake and exportable new production in the subarctic Pacific. J Geophys Res 96:741-748

Banse K (1991b) Rates of phytoplankton cell division in the field and in iron enrichment expenments. Limnol Oceanogr 36:1866-1898

Booth BC, Lewin J, Lorenzen CJ (1988) Spring and summer growth rates of subarctic Pacific phytoplankton assemblages determined from carbon uptake and cell volumes estimated using epifluorescence microscopy. Mar Biol 98: $287-298$

Booth BC, Lewin J, Postel JR (1993) Temporal variation in the structure of autotrophic and heterotrophic communities in the subarctic Pacific. Prog Oceanogr 32:57-99

Bruland KW, Franks RP. Knauer GA, Martın JH (1979) Sampling and analytical methods for the determination of cop- per, cadmium, zinc and nickel at the nanogram per litre level in seawater. Anal Chim Acta 105:233-245

Bruland KW, Orians KJ, Cowen JP (1994) Reactive trace metals in the stratified central North Pacific. Geochim Cosmochim Acta 58:3171-3182

Chavez FP and 7 others (1991) Growth rates, grazing, sinking and ron limitation of equatorial Pacific phytoplankton. Limnol Oceanogr 36:1816-1834

Chisholm SW, Morel FMM (1991) What controls phytoplankton production in nutrient-rich areas of the open sea? Lumnol Oceanogr 36:preface

Coale KH (1991) Effects of iron, manganese, copper and zinc enrichments on productivity and biomass in the subarctic Pacific. Limnol Oceánogr 36:1851-1864

Cochlan WP (1982) Seasonal study of uptake and regeneration of nitrogen on the Scotian Shelf. Cont Shelf Res 15: $555-577$

Cullen JJ (1991) Hypotheses to explain high-nutrient conditions in the open sea. Limnol Oceanogr 36:1578-1599

Dagg M (1993a) Grazing by the copepod community does not control phytoplankton production in the subarctic Pacific Ocean. Prog Oceanogr 32:163-183

Dagg $M(1993 b)$ Sinking particles as a possible source of nutrition for the calanoid copepod Neocalanus cristatus in the subarctic Pacific Ocean. Deep Sea Res I 40:1431-1445

Dugdale RC, Goering JJ (1967) Uptake of new and regenerated forms of nitrogen in primary productivity. Limnol Oceanogr 12:196-206

Dugdale RC, Wilkerson FP (1986) The use of ${ }^{15} \mathrm{~N}$ to measure nitrogen uptake in eutrophic oceans; experimental considerations. Limnol Oceanogr 31:673-689

Eppley RW (1972) Temperature and phytoplankton growth in the sea. Fish Bull 70:1063-1085

Eppley RW, Rogers JN, McCarthy JJ (1969) Half-saturation constants for uptake of nitrate and ammonium by marine phytoplankton. Limnol Oceanogr 14:912-921

Fielder R, Proksch G (1975) The determination of nitrogen-15 by emission and mass spectrometry in biochemical analysis: a review. Anal Chim Acta 78:1-62

Frost BW (1987) Grazing control of phytoplankton stock in the open subarctic Pacific Ocean: a model assessing the role of mesozooplankton, particularly the large calanoid copepods, Neocalanus spp. Mar Ecol Prog Ser 39:49-68

Frost BW (1991) The role of grazing in nutrient-rich areas of the open sea. Limnol Oceanogr 36:1616-1630

Frost BW, Landry MR, Hassett RP (1983) Feeding behaviour of large calanoid copepods Neocalanus cristatus and $N$. plumchrus from the subarctic Pacific Ocean. Deep Sea Res 30:1-13

Fryxell GA, Kaczmarska I (1994) Specific variability in Feenriched cultures from the equatorial Pacific. J Plankton Res 16:755-769

Fulton JD (1978) Seasonal and annual variations of net zooplankton at Ocean Station P, 1965-1976. Can Fish Mar Serv Data Rept 49

Gallegos CL (1989) Microzooplankton grazing on phytoplankton in Rhode River, Maryland: non-linear feeding kinetics. Mar Ecol Prog Ser 57:23-33

Hudson RJM, Morel FMM (1989) Distingushing between extra- and intracellular iron in marine phytoplankton. Limnol Oceanogr 34:1113-1120

Hutchins D, DiTullio GR, Bruland KW (1993) Iron and regenerated production: evidence for biological iron recycling in two different marine environments. Limnol Oceanogr 38:1242-1255

Joint IR, Pomroy AJ (1983) Production of picoplankton and small nanoplankton in the Celtic Sed. Mar Biol 77:19-27 
Joint IR, Pomroy AJ, Savidge G, Boyd P (1993) Size-fractionated primary productivity in the northeast Atlantic in May-July 1989. Deep Sea Res II 40:423-440

Kolber ZS, Barber RT, Coale KH, Fitzwater SE, Greene RM, Johnson KS, Lindley S, Falkowski PG (1994) Iron limitation of phytoplankton photosynthesis in the equatorial Pacific Ocean. Nature 371:145-149

Landry MR (1993) In: Kemp PF, Sherr BF, Sherr EB, Cole JJ (eds) Estimating rates of growth and grazing mortality of photoautotrophic plankton by dilution. Handbook of methods in aquatic microbial ecology. Lewis Publ, Boca Raton, FL, p 715-722

Landry MR, Gifford DJ, Kirchman DL, Wheeler PA, Monger $\mathrm{BC}$ (1993a) Direct and indirect effects of grazing by Neocalanus plumchrus on plankton community dynamics in the subarctic Pacific. Prog Oceanogr 32:239-258

Landry MR, Hassett RP (1982) Determining the grazing impact of marine microzooplankton. Mar Biol 67:283-288

Landry MR, Lehner-Fournier JM (1988) Grazing rates and behaviours of Neocalanus plumchrus: implications for phytoplankton control in the subarctic Pacific. Hydrobiol 167/168:9-19

Landry MR, Monger BC, Selph KE (1993b) Time-dependency of microzooplankton grazing and phytoplankton growth in the subarctic Pacific. Prog Oceanogr 32:205-222

La Roche J (1983) Ammonium regeneration: its contribution to phytoplankton nitrogen requirements in an eutrophic environment. Mar Biol 75:231-240

Mackas DL, Sefton H, Miller CB, Raich A (1993) Vertical habitat partitioning by large calanoid copepods in the oceanic subarctic Pacific during spring. Prog Oceanogr 32: $259-294$

Martin JH (1990) Glacial-interglacial $\mathrm{CO}_{2}$ change: the iron hypothesis. Paleoceanography 5:1-13

Martin JH, Gordon RM (1988) Northeast Pacific iron distributions in relation to phytoplankton productivity. Deep Sea Res 35:177-196

Martin JH, Fitzwater SE, Gordon RM, Broenkow WW (1989) VERTEX: phytoplankton/iron studies in the Gulf of Alaska. Deep Sea Res 36:649-680

McKelvey BA, Orians KJ (1993) Dissolved zirconium in the North Pacific Ocean. Geochim Cosmochim Acta 57: $3801-3805$

Miller CB. Frost BW, Wheeler PA, Landry MR, Welschmeyer $N$, Powell TM (1991) Ecological dynamics in the subarctic Pacific, a possibly iron limited system. Limnol Oceanogr 36:1600-1615

Mitchell BG, Brody EA, Holm-Hansen O, McClain C, Bishop $J$ (1991) Light limitation of phytoplankton biomass and macronutrient utilization in the Southern Ocean. Limnol Oceanogr 36:1662-1677

Muggli DM, LeCourt M, Harrison. PJ (1996) The effects of iron

This article was presented by K. Banse, Seattle, Washington, USA and nitrogen source on the sinking rate, physiology and metal composition of an oceanic diatom from the subarctic Pacific. Mar Ecol Prog Ser 132:215-227

Parsons TR, Maita Y, Lalli CM (1984) A manual of chemical and biological methods for seawater analysis. Pergamon Press, Oxford

Price NM, Harrison GI, Hering JG, Hudson RJ, Nirel PMV, Palenik B, Morel FMM (1990) Preparation and chemistry of the artificial algal culture medium Aquil. Biol Oceanogr 6:503-521

Price NM, Ahner BA, Morel FMM (1994) The equatorial Pacific Ocean: grazer-controlled phytoplankton populations in an iron-limited ecosystem. Limnol Oceanogr 39: $1845-1863$

Price NM, Anderson LF, Morel FMM (1991) Iron and nitrogen nutrition of equatorial Pacific plankton. Deep Sea Res 38: $1361-1378$

Redfield AC (1958) The biological control of chemical factors in the environment. Am Sci 46:205-221

Slawyk G, Maclsaac JJ (1972) Comparison of two automated ammonium methods in a region of coastal upwelling. Deep Sea Res 19:521-524

Strom S, Welschmeyer NA (1991) Pigment-specific rates of phytoplankton growth and microzooplankton grazing in the open subarctic Pacific Ocean. Limnol Oceanogr 36: $50-63$

Sunda WG, Swift DG, Huntsman SA (1991) Low iron requirements for growth in oceanic phytoplankton. Nature 351 : $55-57$

Uematsu M, Duce RA, Prospero JM, Chen L, Merrill JT, MCDonald RL (1983) Transport of mineral aerosol from Asia over the North Pacific Ocean. J Geophy Res 88:5343-5352

Utermöhl H (1958) Zur Vervollkommnung der quantitativen Phytoplankton-Methodik. Mitt Int Ver Theor Angew Limnol 9:38 p

Wells ML, Price NM, Bruland KW (1995) Iron chemistry in seawater and its relationship to phytoplankton: a workshop report. Mar Chem 48:157-182

Wheeler PA, Kokkinakis SA (1990) Ammonium recycling limits nitrate use in the oceanic subarctic Pacific. Limnol Oceanogr 35:1267-1278

Welschmeyer NA, Goericke R, Strom S, Peterson W (1991) Phytoplankton growth and herbivory in the subarctic Pacific: a chemotaxonomic analysis. Limnol Oceanogr 36 : $1631-1449$

Wood ED, Armstrong FAJ, Richards FA (1967) Determination of nitrate in seawater by cadmium-copper reduction to nitrite J Mar Biol Ass UK 47:23-31

Yang L (1993) Determination of trace metals in seawater. MSc thesis, University of British Columbia, Vancouver

Zar JH (1984) Biostatistical Analysis. Prentice-Hall, Englewood Cliffs, NJ

Manuscript first received: May 1, 1995

Revised version accepted: January 23, 1996 